\title{
The recent increase of atmospheric methane from 10 years of ground-based NDACC FTIR observations since 2005
}

\author{
Whitney Bader $^{1,2}$, Benoît Bovy ${ }^{1}$, Stephanie Conway ${ }^{2}$, Kimberly Strong $^{2}$, Dan Smale ${ }^{3}$, Alexander J. Turner ${ }^{4}$, \\ Thomas Blumenstock $^{5}$, Chris Boone ${ }^{6}$, Martine Collaud Coen ${ }^{7}$, Ancelin Coulon ${ }^{8}$, Omaira Garcia ${ }^{9}$, \\ David W. T. Griffith ${ }^{10}$, Frank Hase ${ }^{5}$, Petra Hausmann ${ }^{11}$, Nicholas Jones ${ }^{10}$, Paul Krummel ${ }^{12}$, Isao Murata ${ }^{13}$, \\ Isamu Morino $^{14}$, Hideaki Nakajima ${ }^{14}$, Simon O’Doherty ${ }^{15}$, Clare Paton-Walsh ${ }^{10}$, John Robinson $^{3}$, \\ Rodrigue Sandrin $^{2}$, Matthias Schneider ${ }^{5}$, Christian Servais ${ }^{1}$, Ralf Sussmann ${ }^{11}$, and Emmanuel Mahieu ${ }^{1}$ \\ ${ }^{1}$ Institute of Astrophysics and Geophysics, University of Liège, Liège, Belgium \\ ${ }^{2}$ Department of Physics, University of Toronto, Toronto, ON, M5S 1A7, Canada \\ ${ }^{3}$ National Institute of Water and Atmospheric Research, NIWA, Lauder, New Zealand \\ ${ }^{4}$ School of Engineering and Applied Sciences, Harvard University, Cambridge, MA, USA \\ ${ }^{5}$ Karlsruhe Institute of Technology (KIT), Institute of Meteorology and Climate Research (IMK-ASF), Karlsruhe, Germany \\ ${ }^{6}$ Department of Chemistry, University of Waterloo, Waterloo, ON, N2L 3G1, Canada \\ ${ }^{7}$ Federal Office of Meteorology and Climatology, MeteoSwiss, 1530 Payerne, Switzerland \\ ${ }^{8}$ Institute for Atmospheric and Climate Science, ETH Zurich, Zurich, Switzerland \\ ${ }^{9}$ Izana Atmospheric Research Centre (IARC), Agencia Estatal de Meteorologia (AEMET), Izaña, Spain \\ ${ }^{10}$ School of Chemistry, University of Wollongong, Wollongong, Australia \\ ${ }^{11}$ Karlsruhe Institute of Technology, IMK-IFU, Garmisch-Partenkirchen, Germany \\ ${ }^{12}$ CSIRO Oceans \& Atmosphere, Aspendale, Victoria, Australia \\ ${ }^{13}$ Graduate School of Environment Studies, Tohoku University, Sendai 980-8578, Japan \\ ${ }^{14}$ National Institute for Environmental Studies (NIES), Tsukuba, Ibaraki 305-8506, Japan \\ ${ }^{15}$ Atmospheric Chemistry Research Group (ACRG), School of Chemistry, University of Bristol, Bristol, UK
}

Correspondence to: Whitney Bader (wbader@atmosp.physics.utoronto.ca)

Received: 2 August 2016 - Discussion started: 9 August 2016

Revised: 10 January 2017 - Accepted: 14 January 2017 - Published: 14 February 2017

\begin{abstract}
Changes of atmospheric methane total columns $\left(\mathrm{CH}_{4}\right)$ since 2005 have been evaluated using Fourier transform infrared (FTIR) solar observations carried out at 10 ground-based sites, affiliated to the Network for Detection of Atmospheric Composition Change (NDACC). From this, we find an increase of atmospheric methane total columns of $0.31 \pm 0.03 \%$ year $^{-1}$ ( $2 \sigma$ level of uncertainty) for the 2005-2014 period. Comparisons with in situ methane measurements at both local and global scales show good agreement. We used the GEOS-Chem chemical transport model tagged simulation, which accounts for the contribution of each emission source and one sink in the total methane, simulated over 2005-2012. After regridding according to NDACC vertical layering using a conservative regridding scheme and smoothing by convolving with respective FTIR
\end{abstract}

seasonal averaging kernels, the GEOS-Chem simulation shows an increase of atmospheric methane total columns of $0.35 \pm 0.03 \%$ year $^{-1}$ between 2005 and 2012, which is in agreement with NDACC measurements over the same time period $\left(0.30 \pm 0.04 \%\right.$ year $^{-1}$, averaged over 10 stations $)$. Analysis of the GEOS-Chem-tagged simulation allows us to quantify the contribution of each tracer to the global methane change since 2005. We find that natural sources such as wetlands and biomass burning contribute to the interannual variability of methane. However, anthropogenic emissions, such as coal mining, and gas and oil transport and exploration, which are mainly emitted in the Northern Hemisphere and act as secondary contributors to the global budget of methane, have played a major role in the increase of atmospheric methane observed since 2005. Based on the GEOS- 
Chem-tagged simulation, we discuss possible cause(s) for the increase of methane since 2005, which is still unexplained.

\section{Introduction}

Atmospheric methane $\left(\mathrm{CH}_{4}\right)$, a relatively long-lived atmospheric species with a lifetime of 8-10 years (Kirschke et al., 2013), is the second most abundant anthropogenic greenhouse gas, with a radiative forcing (RF) of $0.97 \pm 0.23 \mathrm{~W} \mathrm{~m}^{-2}$ (including indirect radiative forcing associated with the production of tropospheric ozone and stratospheric water vapour; Stocker et al., 2013) after $\mathrm{CO}_{2}$ (RF in 2011: $1.68 \pm 0.35 \mathrm{~W} \mathrm{~m}^{-2}$, Stocker et al., 2013). Approximately one-fifth of the increase in radiative forcing by human-linked greenhouse gases since 1750 is due to methane (Nisbet et al., 2014). Identified emission sources include anthropogenic and natural contributions. Human activities associated with the agricultural and the energy sectors are the main sources of anthropogenic methane through enteric fermentation of livestock $(17 \%)$, rice cultivation $(7 \%)$, for the former, and coal mining (7\%), oil and gas exploitation $(12 \%)$, and waste management $(11 \%)$, for the latter. On the other hand, natural sources of methane include wetlands $(34 \%)$, termites $(4 \%)$, methane hydrates and ocean $(3 \%)$ along with biomass burning ( $4 \%$ ), a source of atmospheric methane that is both natural and anthropogenic. The abovementioned estimated contributions to the atmospheric content of methane are based on Chen and Prinn (2006), Fung et al. (1991), Kirschke et al. (2013) and on emission inventories used for the GEOS-Chem v9-02 methane simulation (Turner et al., 2015), although it is worth noting that the global budget of methane remains insufficiently understood.

Methane is depleted at the surface by consumption by soil bacteria, in the marine boundary layer by reaction with chlorine atoms, in the troposphere by oxidation with the hydroxyl radical $(\mathrm{OH})$, and in the stratosphere by reaction with chlorine atoms, $\mathrm{O}\left({ }^{1} \mathrm{D}\right), \mathrm{OH}$, and by photodissociation (Kirschke et al., 2013). Due to its sinks, methane has important chemical impacts on the atmospheric composition. In the troposphere, oxidation of methane is a major regulator of $\mathrm{OH}$ (Lelieveld, 2002) and is a source of hydrogen and of tropospheric ozone precursors such as formaldehyde and carbon monoxide (Montzka et al., 2011). In the stratosphere, methane plays a central role as a sink for chlorine atoms and as a source of stratospheric water vapour, an important driver of decadal global surface climate change (Solomon et al., 2010). Given its atmospheric lifetime, and its impact on radiative forcing and on atmospheric chemistry, methane is one of the primary targets for regulation of greenhouse gas emissions and climate change mitigation.

As a result of growing anthropogenic emissions, atmospheric methane showed prolonged periods of increase over the past 3 decades (World Meteorological Organization, 2014). From the 1980s until the beginning of the 1990 s, atmospheric methane was rising sharply by about $\sim 0.7 \%$ year $^{-1}$ (Nisbet et al., 2014) but stabilized during the 1999-2006 time period (Dlugokencky, 2003). Many studies were dedicated to the analysis of methane trends, in particular the stabilization of methane concentrations between 1999 and 2006, and various scenarios have been suggested. They include reduced global fossil-fuel-related emissions (Aydin et al., 2011; Chen and Prinn, 2006; Simpson et al., 2012; Wang et al., 2004), a compensation between increasing anthropogenic emissions and decreasing wetland emissions (Bousquet et al., 2006), and/or significant (Rigby et al., 2008) to small (Montzka et al., 2011) changes in OH concentrations. However, Pison et al. (2013) emphasized the need for a comprehensive and precisely quantified methane budget for its proper closure and the development of realistic future climate scenarios.

Since 2005-2006, a renewed increase of atmospheric methane has been observed and widely discussed in many studies (Bloom et al., 2010; Dlugokencky et al., 2009; Frankenberg et al., 2011; Hausmann et al., 2016; Helmig et al., 2016; Montzka et al., 2011; Rigby et al., 2008; Schaefer et al., 2016; Spahni et al., 2011; Sussmann et al., 2012; van der Werf et al., 2010), leading to various hypotheses. In this work, for the first time, we report of an increase in methane observed since 2005 at a suite of NDACC sites distributed worldwide, operating Fourier transform infrared (FTIR) spectrometers. The paper is organized as follows: Sect. 2 includes a brief description of the 10 participating sites, and the retrieval strategy and degrees of freedom and vertical sensitivity range of the FTIR measurements. Section 3 focuses on the methane changes since 2005 as derived from the NDACC FTIR measurements and the GEOS-Chem model, along with comparisons between both model and observations. This section also provides a source-oriented analysis of the recent increase of methane using the GEOSChem-tagged simulation. Finally, Sect. 4 discusses the potential source(s) responsible for the observed increase of methane since the mid-2000s.

\section{NDACC FTIR observations}

The international Network for the Detection of Atmospheric Composition Change (NDACC) is dedicated to observing and understanding the physical and chemical state of the stratosphere and troposphere. Its priorities include the detection of trends in atmospheric composition, understanding their impacts on the stratosphere and troposphere, and establishing links between climate change and atmospheric composition. 


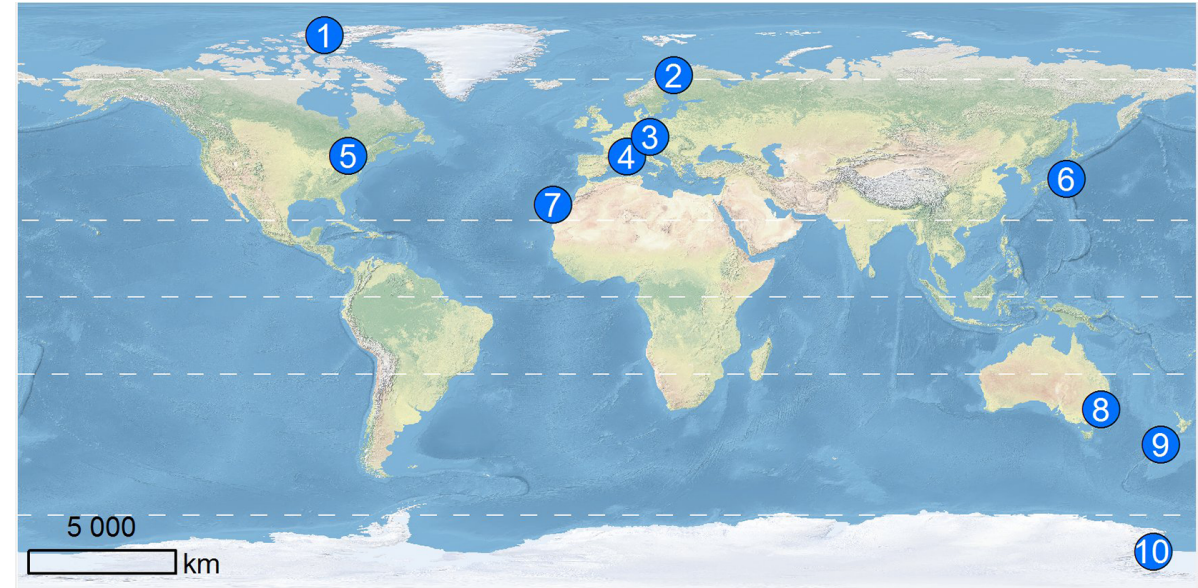

Figure 1. Map of all participating NDACC stations. Detailed coordinates of each station are provided in Table 1.

Table 1. Description of the participating stations.

\begin{tabular}{|c|c|c|c|c|c|c|}
\hline & Station & $\begin{array}{l}\text { Latitude } \\
\qquad\left({ }^{\circ} \mathrm{N}\right)\end{array}$ & $\begin{array}{r}\text { Longitude } \\
\left({ }^{\circ} \mathrm{E}\right)\end{array}$ & $\begin{array}{r}\text { Altitude } \\
(\mathrm{m})\end{array}$ & $\begin{array}{l}\text { No. of } \\
\text { days }^{\text {a }}\end{array}$ & Instrument \\
\hline 1 & Eureka, EUR (CA) & 80.05 & -86.42 & 610 & $619^{\mathrm{b}}$ & Bruker IFS $125 \mathrm{HR}$ \\
\hline 2 & Kiruna, KIR (SE) & 67.84 & 20.39 & 420 & 649 & $\begin{array}{l}\text { Bruker IFS } 120 \mathrm{HR} \\
\text { Bruker IFS } 125 \mathrm{HR}\end{array}$ \\
\hline 3 & Zugspitze, ZUG (DE) & 47.42 & 10.98 & 2954 & 1114 & Bruker IFS $125 \mathrm{HR}$ \\
\hline 4 & Jungfraujoch, JFJ (CH) & 46.55 & 7.98 & 3580 & 1119 & Bruker IFS $120 \mathrm{HR}$ \\
\hline 5 & Toronto, TOR (CA) & 43.66 & -79.4 & 174 & 964 & ABB Bomem DA8 \\
\hline 6 & Tsukuba, TSU (JP) & 36.05 & 140.12 & 31 & 640 & $\begin{array}{l}\text { Bruker IFS 120HR } \\
\text { Bruker IFS } 125 \mathrm{HR}\end{array}$ \\
\hline 7 & Izaña, IZA (ES) & 28.29 & -16.48 & 2370 & 990 & $\begin{array}{l}\text { Bruker IFS } 120 \mathrm{M} \\
\text { Bruker IFS } 125 \mathrm{HR}\end{array}$ \\
\hline 8 & Wollongong, WOL (AU) & -34.41 & 150.88 & 31 & 1612 & $\begin{array}{l}\text { Bomem DA8 } \\
\text { Bruker IFS } 125 \mathrm{HR}\end{array}$ \\
\hline 9 & Lauder, LAU (NZ) & -45.04 & 169.68 & 370 & 1017 & Bruker IFS $120 \mathrm{HR}$ \\
\hline 10 & Arrival heights, AHT (NZ) & -77.83 & 166.65 & 200 & $341^{\mathrm{c}}$ & Bruker IFS 120M \\
\hline
\end{tabular}

\subsection{Observation sites}

Ground-based NDACC FTIR measurements of methane obtained at 10 globally distributed observation sites are presented in this study. These sites, displayed in Fig. 1 and whose location is detailed in Table 1 are located from north to south in Eureka (Arctic, Canada), Kiruna (Sweden), Zugspitze (Germany), Jungfraujoch (Switzerland), Toronto (Canada), Tsukuba (Japan), Izaña (Canary Islands, Spain), Wollongong (Australia), Lauder (New Zealand), and Arrival Heights (Antarctica). Most of the FTIR data are available from the NDACC database (http://www.ndsc.ncep.noaa.gov/ data/).

The Eureka (EUR, Fogal et al., 2013) station is located in the Canadian High Arctic, at 610 m a.s.l. on Ellesmere Island in the northern Canadian Archipelago. The station is located along the Slidre Fjord and is surrounded by complex topography (Cox et al., 2012). This topography, along with its proximity to the Greenland Ice Sheet and atmospheric conditions, make this station ideal for infrared solar measurements in the Arctic as it is frequently under the influence of cold and dry air from the central Arctic and the Greenland Ice Sheet (Cox et al., 2012). Routine solar infrared measurements are taken from late February to late October; no lunar measurements are taken during polar nights (Batchelor et al., 2009).

The Kiruna (KIR) site is located in the boreal forest region of northern Sweden. The spectrometer is operated in the building of the IRF (Institute för Rymdfysik/Swedish Institute of Space Physics), at an altitude of $420 \mathrm{~m}$, about $10 \mathrm{~km}$ away from the centre of Kiruna. The local popula- 
tion and traffic density is low, so the FTIR site is not significantly affected by local anthropogenic emissions. The location just inside the polar circle is especially suited for the study of the Arctic polar stratosphere, because the break in solar absorption observations is still rather short, while the stratospheric polar vortex frequently covers Kiruna in early spring. The solar absorption spectra were obtained with a Bruker IFS-120HR since 1996. In 2007, an electronic upgrade to a Bruker IFS-125HR was implemented. Routine solar infrared measurements are taken between mid-January and mid-November. No lunar measurements are taken during polar nights.

The Zugspitze (ZUG, Sussmann and Schäfer, 1997) station is located on the southern slope of the Zugspitze mountain, the highest mountain in the German Alps (2964 ma.s.1.), at the Austrian border near the town of Garmisch-Partenkirchen (720 m a.s.l.). Its high altitude offers an excellent location for long-term trace gas measurements under unperturbed background atmospheric conditions and it exhibits a very low level of integrated water vapour.

The Jungfraujoch (JFJ, Zander et al., 2008) station is located in the Swiss Alps at an altitude of $3580 \mathrm{~m}$ on the saddle between the Jungfrau (4158 ma.s.l.) and the Mönch (4107 m a.s.1.) summits. This station offers unique conditions for infrared solar observations because of weak local pollution (no major industries within $20 \mathrm{~km}$ ) and very high dryness due to the high altitude and the presence of the Aletsch Glacier in its immediate vicinity. The Jungfraujoch station allows for the investigation of the atmospheric background conditions over central Europe and the mixing of air masses between the planetary boundary layer and the free troposphere (Reimann, 2004).

The Toronto (TOR) station is located in the core of the city of Toronto, Ontario, Canada at $174 \mathrm{~m}$ a.s.l. where regular solar measurements began in 2002. In contrast to most NDACC stations, the Toronto station is highly affected by the densely populated areas of the city of Toronto itself (the centre of Canada's largest population) and the cities and industrial centres of the north-eastern United States, enabling measurements of tropospheric pollutants (Whaley et al., 2015). In addition, the station's location makes it well suited for measurements of midlatitude stratospheric ozone, related species, and greenhouse gases (Wiacek et al., 2007).

The Tsukuba (TSU) station is located in a suburban area (around $50 \mathrm{~km}$ from Tokyo) in a large plain with many rice paddies, at an altitude of $31 \mathrm{~m}$. The station occasionally captures local pollution and is affected by high humidity during the summer season. The Tsukuba solar absorption spectra were obtained with a Bruker IFS-120HR from May 2001 to March 2010 and replaced by a Bruker IFS-125HR in April 2010.

The Izaña observatory (IZA, http://www.izana.org) is located on the top of a mountain plateau in the Teide National Park on the Island of Tenerife. It is usually located above a strong subtropical temperature inversion layer (generally well established between 500 and $1500 \mathrm{~m}$ a.s.l.) and clean-air and clear-sky conditions prevail year-round. Consequently it offers excellent conditions for the remote sensing of trace gases and aerosols under free tropospheric conditions and for atmospheric observations. Due to its geographic location, it is particularly valuable for the investigation of dust transport from Africa to the North Atlantic, and large-scale transport from the tropics to higher latitudes. In addition, during the daytime the strong insolation generates a slight upslope flow of air originating from below the inversion layer (from a woodland that surrounds the station at a lower altitude; Sepúlveda et al., 2012). The solar absorption spectra were obtained with a Bruker IFS 120M over 1999-2004, then with a Bruker IFS 125HR (Sepúlveda et al., 2012).

Wollongong (WOL, Griffith et al., 1998) is a coastal city about $80 \mathrm{~km}$ south of the metropolis of Sydney. Its urban location, in proximity to Sydney and local coal mining operations means that enhanced levels of $\mathrm{CH}_{4}$ are measured from time to time. Climatologically the winds are weak $\left(<4 \mathrm{~m} \mathrm{~s}^{-1}\right)$; during the Southern Hemisphere winter the site largely samples continental air masses from the west, with summer afternoon sea breezes from the east-north-east (Fraser et al., 2011). The solar absorption spectra were obtained with a Bomem DA8 from 1995 to 2007 (Griffith et al., 1998) and with a Bruker IFS 125/HR from 2007 onwards.

The Lauder (LAU) atmospheric research station is located in the Manuherikia valley, Central Otago, New Zealand. The site experiences a continental climate of hot dry summers and cool winters with a predominating westerly wind. The site is sparsely populated and remote from any major industries with non-intense agricultural and horticulture as the mainstay of economic activity.

The Arrival Heights (AHT) atmospheric laboratory is located $3 \mathrm{~km}$ north of McMurdo and Scott Base stations on Hut Point Peninsula, the southern volcanic peninsula of Ross Island. With minimal exposure to local anthropogenic pollution and sources, methane measurements conducted at Arrival Heights are representative of a well-mixed boundary layer and free troposphere. Located at $78^{\circ} \mathrm{S}$, Arrival Heights is periodically underneath the polar vortex depending on the season, polar vortex shape, and angular rotation velocity. Climatological surface meteorological conditions experienced at Arrival Heights are similar to those at Scott Base (Turner et al., 2004). Routine solar infrared measurements are carried out during the austral spring and summer seasons (late $\mathrm{Au}-$ gust to mid-April) no measurements are taken during polar nights.

\subsection{FTIR observations of methane}

\subsubsection{Retrieval strategies}

A retrieval strategy for the inversion of atmospheric methane time series from ground-based FTIR observations has been carefully developed and optimized for each station. However, 

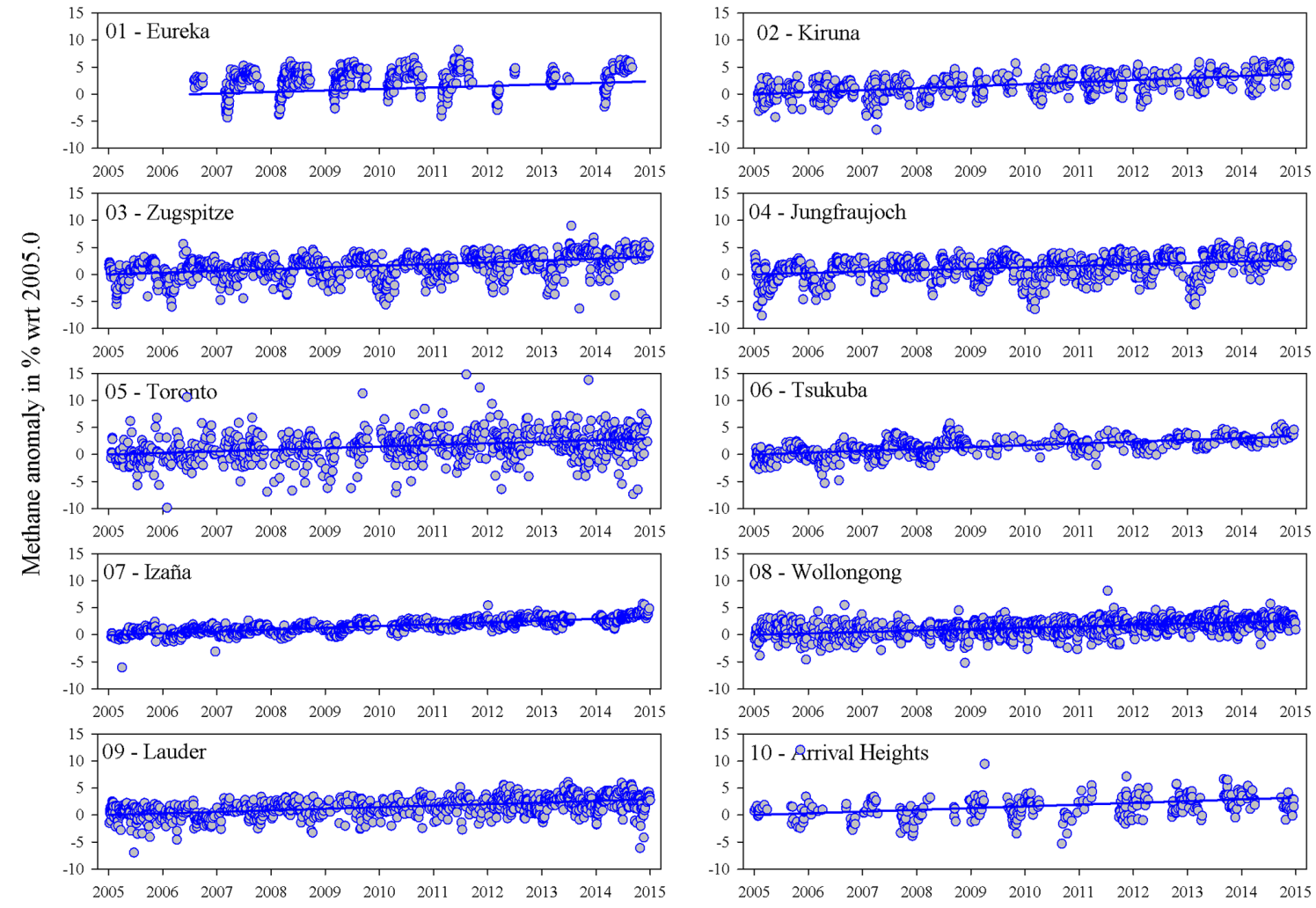

Figure 2. Daily mean methane anomaly with respect to 2005.0 or 2006.0 (in \%) for 10 NDACC stations between 2005 and 2014 . The blue line is the linear component of the bootstrap fit (see Sect. 3).

it is worth mentioning that given the remaining inconsistencies affecting the methane spectroscopic parameters, even in the latest editions of HITRAN (Rothman et al., 2013 and references therein), the harmonization of retrieval strategies for methane for the whole infrared working group of NDACC is still ongoing. To this day, FTIR measurements are analysed as recommended either by Rinsland et al. (2006), Sussmann et al. (2011), or Sepúlveda et al. (2012). Table A1 presents the retrieval parameters used for each station. The retrieval codes PROFFIT (Hase, 2000) and SFIT-2/SFIT-4 (Rinsland et al., 1998) have been shown to provide consistent results for tropospheric and stratospheric species (Duchatelet et al., 2010; Hase et al., 2004). The time series produced using the strategies described in Table A1 are illustrated in Fig. 2. In order to better illustrate the observed increase of methane total columns, the various panels show daily mean methane time series expressed as anomalies with respect to a reference column in 2005.0 (2006.0 for the Eureka station), according to the following equation:

Anomaly $=\frac{C-C_{05}}{\left(C+C_{05}\right) \times 1 / 2} \times 100$,

where $C$ is the methane total column and $C_{05}$ the methane total column at the time 2005.0 derived from the linear component of a Fourier series (Gardiner et al., 2008) fitted to the time series. The reference columns are given for each station in Table 2. It should be mentioned that the Toronto methane columns from 2008 to early 2009 present a systematic error due to an unknown instrument artefact. The data set was corrected by adding a constant offset to the data over that period. To do this, a linear regression was first fit to the full data set (20 June 2002 to 13 December 2014), excluding the biased data, and then another was fit to the biased data only (1 January 2008 to 19 March 2009) using the same fixed slope. The difference between the two intercepts gives a constant offset of molecules $\mathrm{cm}^{-2}$, which was added to the biased data.

In order to investigate the possible impact of the choice of the microwindows and spectroscopy on the retrieved methane, each strategy has been tested over a set of spectra recorded at the Jungfraujoch station (3068 spectra recorded between 1 January 2005 and 31 December 2012). Mean fractional differences between the strategies described in Table 2 have been computed to quantify a potential absolute bias in terms of total columns and changes over the 2005-2012 time period with the inversion strategy optimized for the Jungfraujoch observations set as a reference. Mean fractional differences are defined as the difference between two data sets divided by their arithmetic average and expressed in percent (see Eq. 2 in Strong et al., 2008). This results in an averaged bias between total columns of $0.9 \pm 0.5 \%$ but no bias 


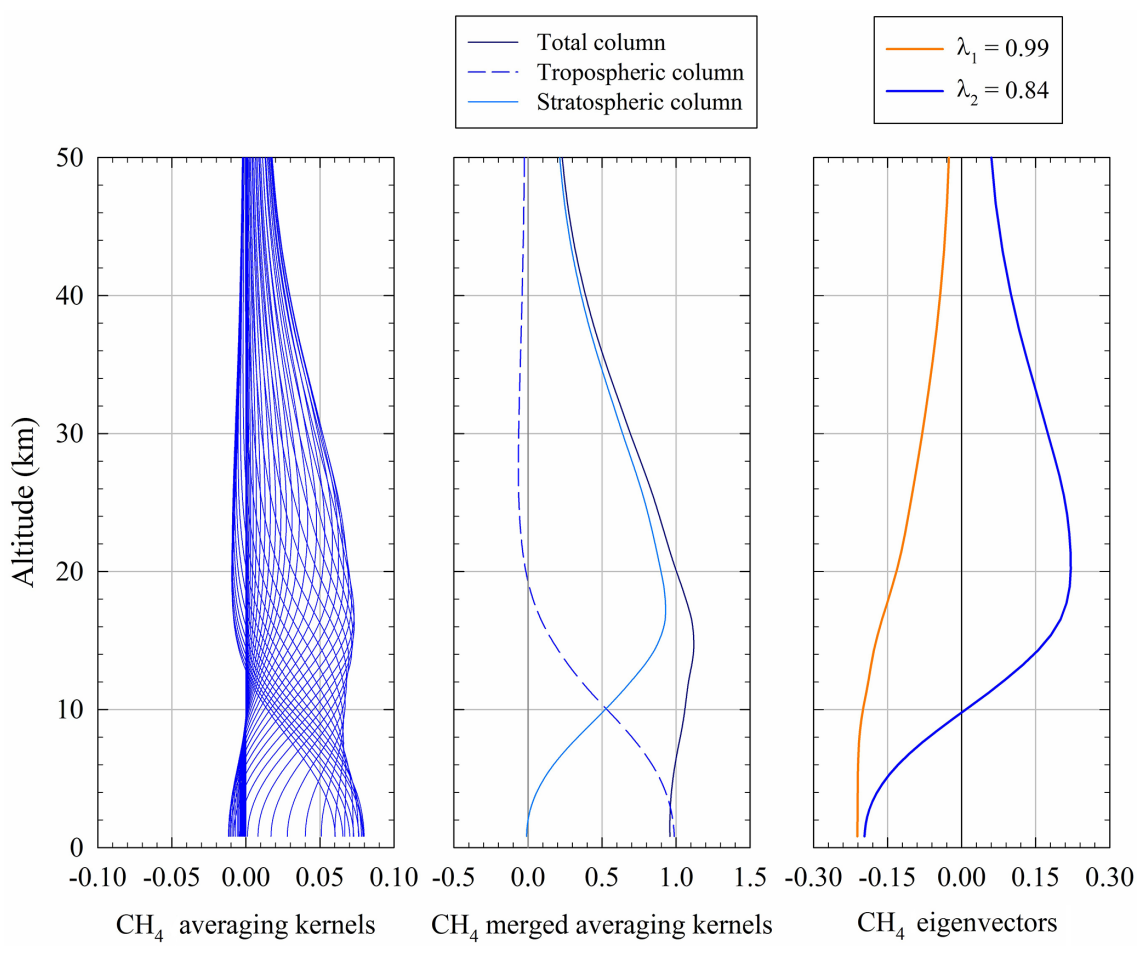

Figure 3. Typical NDACC methane retrieval. From left to right. First panel: typical individual (blue curves) $\mathrm{CH}_{4}$ mixing ratio averaging kernels. Second panel: merged (shades of blue curves) $\mathrm{CH}_{4}$ mixing ratio averaging kernels. For merged-layer kernels, corresponding atmospheric column are specified in the legend box. Third panel: corresponding two first eigenvectors. Associated eigenvalues are given in the legend.

between their respective trends since 2005 is observed (reference values associated with the JFJ strategy in Table A1 are a mean total column of $2.4121 \pm 0.0055 \times 10^{19}$ molecules $\mathrm{cm}^{-2}$ and a mean annual change of $0.22 \pm 0.04 \%$ year $^{-1}$ with respect to 2005.0).

\subsubsection{Degrees of freedom and vertical sensitivity range}

Due to the previously mentioned unresolved discrepancies associated with methane spectroscopic parameters, it has been established within the NDACC Infrared Working Group that the regularization strength of the methane retrieval strategy should be optimized so that the degrees of freedom for signal (DOFS) is limited to a value of approximately 2 (Sussmann et al., 2011). As a consequence, the typical information content of NDACC methane retrievals will allow us to retrieve tropospheric and stratospheric columns, as displayed in Fig. 3. Indeed, the first eigenvector (in green) and its associated eigenvalue (typically close to 1) show that the corresponding information mainly comes from the retrieval (>99\%), allowing us to retrieve a partial column ranging from the surface up to $30 \mathrm{~km}$. In addition, the second eigenvector allows for a finer vertical resolution with two supplementary partial columns typically around $1 \%$ of a priori dependence: (i) a tropospheric column (typically from the surface to the vicinity of the mean tropopause height of the sta- tion) along with (ii) a stratospheric column (from around the mean tropopause height to $30 \mathrm{~km}$ ). In terms of error budget, extensive error analysis has been performed by Sepúlveda et al. (2014) and Sussmann et al. (2011). It has been determined that spectroscopic parameters almost exclusively determine the systematic error and amount to $\sim 2.5 \%$ while statistical errors, dominated by baseline uncertainties and measurement noise, sum up to $\sim 1 \%$ (Sepúlveda et al., 2014).

As illustrated in Fig. 3, the information content of our retrievals sets the upper and lower limits of our tropospheric and stratospheric columns respectively at the vicinity of the mean tropopause height of the station. Therefore, the typical vertical sensitivity range of our retrieval restricts our definition of a purely tropospheric component. Indeed, our tropospheric column as previously defined may potentially include a stratospheric contribution due to tropopause altitude variation, hence preventing the sampling of the free tropospheric column in some cases (Sepúlveda et al., 2014).

\section{Methane changes since 2005}

We characterize the global increase of methane total column from 10 NDACC stations since 2005 and over 10 years' worth of observations, with a mean annual growth ranging from $0.26 \pm 0.02$ (Wollongong, $2 \sigma$ level of uncertainty) to 
Table 2. Absolute (in molecules $\mathrm{cm}^{-2}$ year $^{-1}$ ) and relative (in $\%$ year ${ }^{-1}$ ) annual change of methane total columns and its associated $2 \sigma-$ uncertainties from FTIR observations and the GEOS-Chem methane simulation with respect to 2005.0 and to the reference column given in molecules $\mathrm{cm}^{-2}$ in the fifth and last columns of this table respectively. The systematic bias between FTIR and GEOS-Chem for 2005-2012 and its associated $2 \sigma$-uncertainties are given in the sixth column. A positive bias can be translated into an overestimation of the GEOS-Chem simulation.

\begin{tabular}{|c|c|c|c|c|c|c|c|c|c|}
\hline \multirow[b]{2}{*}{ Unit } & \multicolumn{2}{|c|}{$\begin{array}{l}\text { FTIR trend } \\
(2005-2014)\end{array}$} & \multicolumn{2}{|c|}{$\begin{array}{l}\text { FTIR trend } \\
(2005-2012)\end{array}$} & \multirow{2}{*}{$\begin{array}{r}\text { FTIR } \\
\begin{array}{r}\text { Reference } \\
\text { Column }\end{array} \\
\times 10^{19} \\
\text { molec cm }^{-2}\end{array}$} & \multirow{2}{*}{$\frac{\text { Bias }}{\%}$} & \multicolumn{2}{|c|}{$\begin{array}{l}\text { GEOS-Chem trend } \\
(2005-2012)\end{array}$} & \multirow{2}{*}{$\begin{array}{r}\begin{array}{r}\text { GEOS-Chem } \\
\text { Reference } \\
\text { Column }\end{array} \\
\times 10^{19} \\
\text { molec cm }^{-2}\end{array}$} \\
\hline & $\begin{array}{r}\times 10^{16} \mathrm{molec}^{-2} \\
\mathrm{~cm}^{-2} \mathrm{yr}^{-1}\end{array}$ & $\% \mathrm{yr}^{-1}$ & $\begin{array}{l}\times 10^{16} \mathrm{molec}^{-2} \mathrm{yr}^{-1}\end{array}$ & $\% \mathrm{yr}^{-1}$ & & & $\begin{array}{r}\times 10^{16} \mathrm{molec}^{-2} \mathrm{~cm}^{-1}\end{array}$ & $\% \mathrm{yr}^{-1}$ & \\
\hline EUR & $9.54 \pm 1.79$ & $0.28 \pm 0.05$ & $10.81 \pm 3.47$ & $0.32 \pm 0.10$ & $3.41^{*}$ & $0.9 \pm 2.9$ & $12.35 \pm 2.06$ & $0.36 \pm 0.06$ & 3.46 \\
\hline KIR & $13.26 \pm 1.46$ & $0.37 \pm 0.04$ & $11.7 \pm 2.04$ & $0.33 \pm 0.06$ & 3.54 & $-1.0 \pm 1.5$ & $12.04 \pm 1.66$ & $0.34 \pm 0.05$ & 3.53 \\
\hline ZUG & $8.33 \pm 0.80$ & $0.32 \pm 0.03$ & $7.99 \pm 1.09$ & $0.31 \pm 0.04$ & 2.58 & $-0.7 \pm 1.2$ & $8.09 \pm 0.93$ & $0.32 \pm 0.04$ & 2.56 \\
\hline JFJ & $6.41 \pm 0.81$ & $0.27 \pm 0.03$ & $5.39 \pm 1.04$ & $0.22 \pm 0.04$ & 2.40 & $-0.8 \pm 1.5$ & $7.31 \pm 0.78$ & $0.31 \pm 0.03$ & 2.38 \\
\hline TOR & $10.99 \pm 3.03$ & $0.29 \pm 0.08$ & $12.85 \pm 3.76$ & $0.34 \pm 0.10$ & 3.71 & $0.4 \pm 5.9$ & $12.45 \pm 1.01$ & $0.33 \pm 0.03$ & 3.75 \\
\hline TSU & $12.99 \pm 1.13$ & $0.34 \pm 0.03$ & $13.90 \pm 1.58$ & $0.36 \pm 0.04$ & 3.82 & $-3.2 \pm 3.1$ & $13.36 \pm 1.17$ & $0.36 \pm 0.03$ & 3.69 \\
\hline IZA & $9.56 \pm 0.35$ & $0.33 \pm 0.01$ & $8.96 \pm 0.48$ & $0.31 \pm 0.02$ & 2.87 & $-0.9 \pm 1.3$ & $10.34 \pm 0.34$ & $0.36 \pm 0.01$ & 2.83 \\
\hline WOL & $9.62 \pm 0.80$ & $0.26 \pm 0.02$ & $8.33 \pm 1.18$ & $0.23 \pm 0.03$ & 3.69 & $0.6 \pm 1.9$ & $13.63 \pm 0.74$ & $0.37 \pm 0.02$ & 3.69 \\
\hline LAU & $9.87 \pm 0.95$ & $0.29 \pm 0.03$ & $9.81 \pm 1.34$ & $0.29 \pm 0.04$ & 3.41 & $2.3 \pm 1.7$ & $11.46 \pm 1.15$ & $0.33 \pm 0.03$ & 3.48 \\
\hline AHT & $10.53 \pm 2.39$ & $0.32 \pm 0.07$ & $9.70 \pm 3.48$ & $0.29 \pm 0.11$ & 3.28 & $4.8 \pm 3.5$ & $14.53 \pm 2.02$ & $0.43 \pm 0.06$ & 3.41 \\
\hline Mean & $10.11 \pm 2.03$ & $0.31 \pm 0.03$ & $9.94 \pm 2.50$ & $0.30 \pm 0.04$ & - & & $11.56 \pm 2.35$ & $0.35 \pm 0.03$ & - \\
\hline
\end{tabular}

* Reference column for Eureka is for 2006.0 since no measurements are available before then. The bottom line of the table shows the average of the 10 mean annual trends.

$0.39 \pm 0.09 \%$ year $^{-1}$ (Toronto). Observational methane time series anomalies and their changes (along with their associated uncertainties) since 2005.0, illustrated in green in Fig. 4 and detailed in Table 2, have been analysed for all 10 sites using the statistical bootstrap resampling tool. They account for a linear component and a Fourier series, taking into account the intra-annual variability of the data set (Gardiner et al., 2008). As in Mahieu et al. (2014), the order of the Fourier series is adapted to each data set depending on its sampling, i.e. limiting the order for the polar sites for which only a partial representation of the seasonality is available. Anomalies of methane total column time series, illustrated in Figs. 2 and 5, have been computed using the methane total column computed by the linear component of the statistical bootstrap tool on 1 January 2005, as a reference. Table 2 shows trends of methane total column computed from FTIR observations over the 2005-2014 and 2005-2012 time periods as well as from a tagged GEOS-Chem simulation between 2005 and 2012. The latter is further discussed in Sect. 3.1.2.

On a regional scale, we compared our results with annual changes of methane as computed over the 2005-2014 time period from surface GC-MD observations (Gas Chromatography - MultiDetector) carried out in the framework of the AGAGE programme (Advanced Global Atmospheric Gases Experiment, Prinn et al., 2000) and from in situ surface measurements taken in the framework of the NOAA (National Oceanic and Atmospheric Administration) ESRL (Earth System Research Laboratory) carbon cycle air sampling network (Dlugokencky et al., 2015). Five representative observation sites have been considered: Alert (Nunavut, Canada, $82.45^{\circ} \mathrm{N},-62.51^{\circ} \mathrm{E}, 200.00 \mathrm{~m}$ a.s.l., Dlugokencky et al., 2015), Mace Head (Ireland, $53.33^{\circ} \mathrm{N},-9.90^{\circ} \mathrm{E}$,

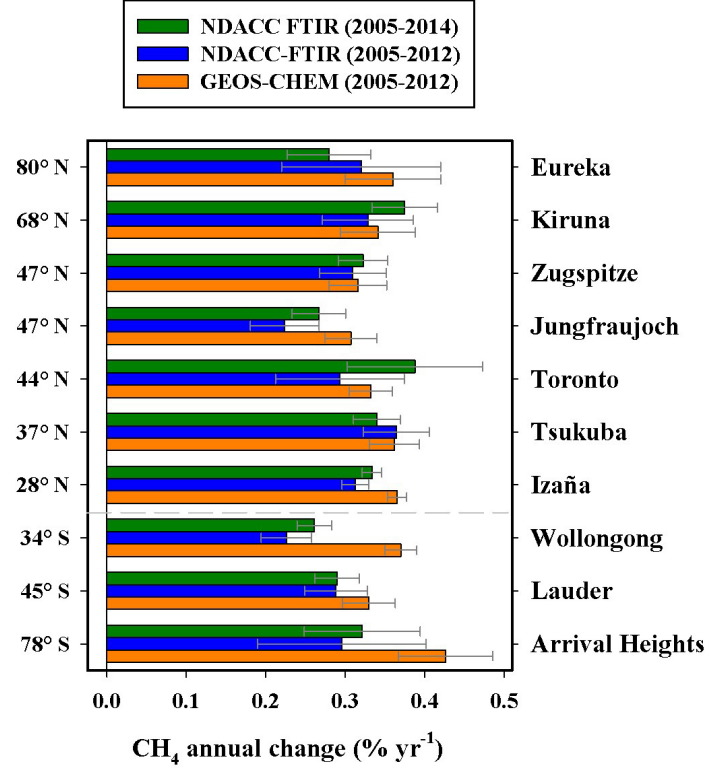

Figure 4. Methane total column mean annual change in $\%$ year $^{-1}$ with respect to 2005.0 (2006.0 for Eureka), for the FTIR time series between 2005 and 2014 (in blue), the NDACC FTIR time series between 2005 and 2012 (in dark blue), and the GEOS-Chem simulation between 2005 and 2012 (in orange). Grey error bars represent $2 \sigma$ uncertainty.

$5.00 \mathrm{~m}$ a.s.1., Prinn et al., 2000), Izaña $\left(28.29^{\circ} \mathrm{N}, 16.48^{\circ} \mathrm{W}\right.$, 2372.90 ma.s.1., Dlugokencky et al., 2015), Cape Grim (Australia, $40.68^{\circ} \mathrm{S}, 144.69^{\circ} \mathrm{E}, 94.00 \mathrm{~m}$ a.s.l., Prinn et al., 2000), and Halley (United Kingdom, $75.61^{\circ} \mathrm{S}, 26.21^{\circ} \mathrm{W}$, 30.00 m a.s.l., Dlugokencky et al., 2015). 
Firstly, in situ measurements collected at Alert, representative of the northern polar region, show an increase of methane of $0.29 \pm 0.02 \%$ year $^{-1}$ (or $5.40 \pm 0.41 \mathrm{ppbyear}^{-1}$ ) since 2006, which is in agreement with our FTIR observations at Eureka with a mean annual change of $0.28 \pm 0.05 \%$ year $^{-1}$. For the northern midlatitudes, we find an agreement between changes of methane as computed from surface measurements at Mace Head with an increase of $0.30 \pm 0.02 \%$ year $^{-1}$ (or $5.58 \pm 0.32 \mathrm{ppbyear}^{-1}$ ) and from our FTIR observations. Indeed, we observe consistent increases of methane of $0.32 \pm 0.03,0.27 \pm 0.03$, and $0.29 \pm 0.08 \%$ year $^{-1}$ since 2005 at Zugspitze, Jungfraujoch, and Toronto. Comparisons between changes of methane from FTIR and in situ surface measurements have also been taken for the Izaña station and show a close to statistical agreement with a mean annual increase of $0.33 \pm 0.01$ and $0.28 \pm 0.02 \%$ year $^{-1}$ respectively. In the Southern Hemisphere, AGAGE GCMD measurements of methane at Cape Grim, representative of the midlatitudes, shows a mean annual increase of $0.31 \pm 0.01 \%$ year $^{-1}$ (or $5.40 \pm 0.16$ ppb year $^{-1}$ ) which is in agreement with FTIR changes at Lauder of $0.29 \pm 0.03 \%$ year $^{-1}$. However, we should note the slightly larger mean annual changes of methane of Cape Grim in situ observations with respect to Wollongong FTIR measurements. Indeed, it needs to be mentioned that FTIR measurements before the instrument change in 2007 (Bomem DA8 vs. Bruker IFS 125HR; see Table 1) show noisier results. These noisier observations at the beginning of the time period under investigation may affect the relatively small annual changes of methane overall. As a result, the 2005-2007 time series shows no changes of methane while the 2007-2014 time period shows a mean annual change of $0.32 \pm 0.03 \%$ year $^{-1}$ (or $11.94 \pm 1.03 \times$

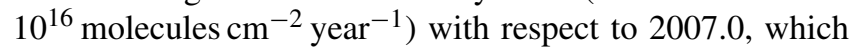
is in agreement with both Lauder FTIR and Cape Grim GCMD methane changes since 2005. Finally, we computed a mean annual change of methane of $0.32 \pm 0.01 \%$ year $^{-1}$

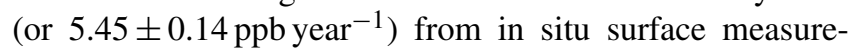
ments taken at Halley, which is in good agreement with the mean annual change of methane computed from FTIR Arrival Heights retrievals that amounts to $0.32 \pm 0.07 \%$ year $^{-1}$.

In summary, we observe from NDACC FTIR measurements a global average annual change of methane of $0.31 \pm 0.03 \%$ year $^{-1}$ (averaged over 10 stations, $2 \sigma$ level of uncertainty) which is in agreement with a mean annual change of $0.31 \pm 0.01 \%$ year $^{-1}$ (or $5.51 \pm 0.17$ ppb year $^{-1}$ ), as computed from the monthly global means of baseline data derived from AGAGE measurements (Prinn et al., 2000).

In addition, analyses of tropospheric and stratospheric partial columns changes show tropospheric mean annual changes of methane that are statistically in agreement (at the $2 \sigma$ level) with changes of total column over the 20052014 time period. Mean annual changes from the Atmospheric Chemistry Experiment Fourier transform spectrometer methane research product (ACE-FTS, Bernath et al.,
2005) have also been examined. For consistent comparison, ACE-FTS stratospheric columns of methane have been defined in the same way as the stratospheric FTIR product, i.e. from the average tropopause height of the station to $30 \mathrm{~km}$. Changes of stratospheric methane according to ACE-FTS retrievals are statistically in agreement with our NDACC FTIR changes of stratospheric columns and show small to non-significant changes of methane in the stratosphere. Indeed, changes of stratospheric methane according to the ACE-FTS methane research product (Buzan et al., 2016) are not significant and amount to $-0.12 \pm 0.13 \%$ year $^{-1}$ for the northern high latitudes, $0.10 \pm 0.30$ for northern midlatitudes, $0.08 \pm 0.24$ for the tropical region, $-0.10 \pm 0.31$ for the southern midlatitudes, and $-0.04 \pm 0.14 \%$ year $^{-1}$ for the southern high latitudes.

\subsection{GEOS-Chem-tagged simulation}

GEOS-Chem (version 9-02: http://acmg.seas.harvard.edu/ geos/doc/archive/man.v9-02/index.html, Turner et al., 2015) is a global 3-D chemistry transport model (CTM) capable of simulating global trace gas and aerosol distributions. GEOS-Chem is driven here by assimilated meteorological fields from the Goddard Earth Observing System version 5 (GEOS-5) of the NASA Global Modeling Assimilation Office (GMAO). The GEOS-5 meteorological data have a temporal frequency of $6 \mathrm{~h}$ ( $3 \mathrm{~h}$ for mixing depths and surface properties) and are at a native horizontal resolution of $0.5^{\circ} \times 0.667^{\circ}$ with 72 hybrid pressure- $\sigma$ levels describing the atmosphere from the surface up to $0.01 \mathrm{hPa}$. In the framework of this study, the GEOS-5 fields are degraded for model input to a $2^{\circ} \times 2.5^{\circ}$ horizontal resolution and 47 vertical levels by collapsing levels above $\sim 80 \mathrm{hPa}$. GEOS-Chem has been extensively evaluated in the past (van Donkelaar et al., 2012; Park et al., 2006, 2004; Zhang et al., 2011, 2012). These studies show a good simulation of global transport with no apparent biases.

Emissions for the GEOS-Chem simulations are from the EDGAR v4.2 anthropogenic methane inventory (European Commission, 2011), the wetland model from Kaplan (2002) as implemented by Pickett-Heaps et al. (2011), the GFED3 biomass burning inventory (van der Werf et al., 2010), a termite inventory and soil absorption from Fung et al. (1991), and a biofuel inventory from Yevich and Logan (2003). Wetland emissions vary with local temperature, inundation, and snow cover. Open fire emissions are specified with $8 \mathrm{~h}$ temporal resolution. Other emissions are assumed seasonal. Methane loss is mainly by reaction with the $\mathrm{OH}$ radical. We use a 3-D archive of monthly average $\mathrm{OH}$ concentrations from Park et al. (2004). The resulting atmospheric lifetime of methane is 8.9 years, consistent with the observational constraint of $9.1 \pm 0.9$ years (Prather et al., 2012).

The GEOS-Chem model output presented here covers the period January 2005-December 2012, for which the GEOS5 meteorological fields are available. For this simulation, we 
use the best emission inventories available as implemented in version 9-02 of the model and rely on the spatial and temporal distributions of emissions. This tagged simulation includes 11 tracers: 1 tracer for the soil absorption sink (sa) and 10 tracers for sources: gas and oil (ga), coal (co), livestock (li), waste management (wa), biofuels (bf), rice cultivation (ri), biomass burning (bb), wetlands (wl), other natural emissions (on) and other anthropogenic (oa) emissions. We have used a 1-year run for spin-up from January to December 2004, restarted 70 times for initialization of the tracer concentrations. The model outputs consist of methane mixing ratio profiles saved at a $3 \mathrm{~h}$ time frequency and at the closest pixel to each NDACC station. To account for the vertical resolution and sensitivity of the FTIR retrievals, the individual concentration profiles simulated by GEOS-Chem are interpolated onto the FTIR vertical grid (see next section for description of regridding).

\subsubsection{Data regridding and processing}

In order to perform a proper comparison between the GEOSChem outputs and our NDACC FTIR observations, we accounted for their respective spatial domains and used a conservative regridding scheme so that the total mass of the tracer is preserved (both locally and globally over the entire vertical profile). This was achieved using an algorithm similar to the one described in Sect. 3.1 of Langerock et al. (2015). To this end, time-dependent elevation coordinates are first calculated for the model outputs using gridbox height data and topography data are regridded onto the GEOS-Chem horizontal grid before conservative regridding.

The model outputs (source grid) are then regridded onto an observation-compliant destination grid through our conservative regridding scheme that includes a nearest-neighbour interpolation and a vertical regridding. The vertical destination grid corresponds to the retrieval grid adopted for each station. Regridded fields (tracer mixing-ratio) may have undefined values for cells of the destination grid that do not overlap with the model source grid. For grid cells that partially overlap the model grid, we apply a "mask tolerance", i.e., a relative overlapping volume threshold below which the value of the grid cell will be set as undefined. This may introduce conservation errors, but since partially overlapping cells are likely to occur only at the top level of the model vertical grid, these errors can be neglected for species that usually have a low mixing ratio at that level, such as methane.

To account for the vertical resolution and sensitivity of the FTIR retrievals, the individual concentration profiles simulated by GEOS-Chem are averaged into daily profiles (including day and night simulation) and smoothed according to:

$\boldsymbol{x}_{\text {smooth }}=\boldsymbol{x}_{\mathrm{a}}+\mathbf{A}\left(\boldsymbol{x}_{\mathrm{m}}-\boldsymbol{x}_{\mathrm{a}}\right)$,

where $\mathbf{A}$ is the FTIR averaging kernels, $\boldsymbol{x}_{\mathrm{m}}$ is the daily mean profile as simulated by the GEOS-Chem model regridded to the observation retrieval grid and $\boldsymbol{x}_{\mathrm{a}}$ the FTIR a priori used in the retrieval according to the formalism of Rodgers (1990). Averaging kernels are seasonal averages combining individual matrices from FTIR retrievals. Concerning the methane tracers, we constructed vertical a priori profiles for each of them by scaling the methane a priori employed for each station in order to smooth them as well. To this end, we determined for the 10 sites the contribution of each tracer to the total methane on the basis of the mean budget simulated by the model over the 2005-2012 time period.

\subsubsection{GEOS-Chem simulation vs NDACC FTIR observations}

As we previously pointed out, since the information content of the FTIR retrievals prevents a pure tropospheric component from being retrieved, we will focus on comparisons between FTIR and GEOS-Chem total columns. Due to the availability of the GEOS-5 meteorological fields and to ensure consistency, we limited our comparison of methane changes between FTIR observations and the GEOS-Chem simulation over the 2005-2012 time period. It is, however, worth mentioning that methane changes as observed by our FTIR observations are in agreement for all 10 stations (see Fig. 4 and Table 2) between both time periods, i.e. 20052012 and 2005-2014.

Firstly, comparisons between FTIR observations and the smoothed GEOS-Chem simulation over the 2005-2012 time period have been performed for each NDACC station on days when observations are available. Both time series are illustrated in Fig. 5 as anomalies with respect to 2005.0 (see corresponding reference columns in Table 3 ). We report a good agreement between FTIR and GEOS-Chem methane with no systematic bias (see definition of mean fractional differences given in Sect. 2.2.1 and Eq. 2 in Strong et al., 2008), except for the Tsukuba, Lauder and Arrival Heights stations where GEOS-Chem shows a systematic bias of $-3.2 \pm 3.1$, $2.3 \pm 1.7$, and $4.8 \pm 3.5 \%$ ( $2 \sigma$ level of uncertainty), with their respective FTIR observations. Since we defined the methane anomaly at $0 \%$ in 2005.0 (or 2006.0 for Eureka) for both our observations and the GEOS-Chem simulation, we consequently corrected this observed bias in Fig. 5. On the other hand, we observe a slight phase offset between FTIR and GEOS-Chem seasonal cycles for Izaña and Tsukuba. Indeed, GEOS-Chem simulates the maximum methane column 85 days ahead of FTIR measurements for Izaña while it shows a delay of 92 days with respect to the Tsukuba FTIR time series. It should, however, be pointed out that the seasonal cycle's amplitude is well reproduced by GEOS-Chem with a peak-to-peak amplitude of $5.0 \pm 0.9 \%$ for Tsukuba and of $3.6 \pm 0.5 \%$ for Izaña while the methane seasonal cycle from FTIR measurements shows a peak-to-peak amplitude of $5.9 \pm 1.7$ and $4.3 \pm 1.8 \%$ respectively.

Regarding the increase of methane, the simulation by GEOS-Chem indicates a mean annual increase ranging from 

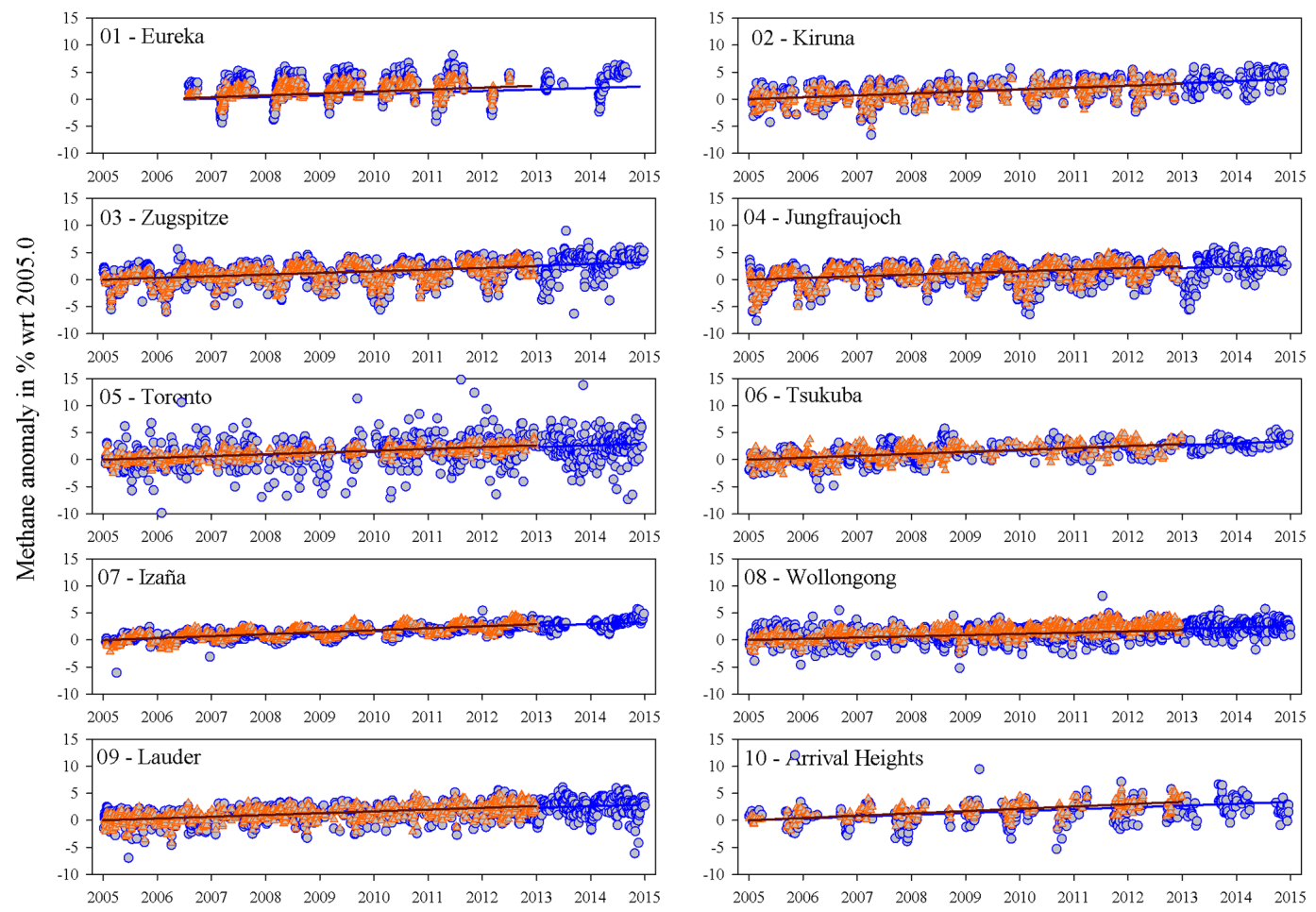

Figure 5. Daily mean $\mathrm{CH}_{4}$ total column anomalies with respect to 2005.0 (in \%) for 10 NDACC stations between 2005 and 2014 for NDACC FTIR observations (in blue) and between 2005 and 2012 for the smoothed GEOS-Chem simulation (in orange) along with their respective linear component of the bootstrap fit in blue and brown.

$0.31 \pm 0.03$ to $0.43 \pm 0.06 \%$ year $^{-1}$ and a globally averaged annual change of $0.35 \pm 0.03 \%$ year $^{-1}$ with respect to 2005.0 (averaged over 10 stations, $2 \sigma$ level of uncertainty). Mean annual changes of total columns of methane between 2005 and 2012 for both FTIR measurements and the GEOSChem simulation are illustrated in Fig. 4 in blue and orange respectively. In terms of the methane increase, the model is in good agreement (within error bars) with the observations except for Jungfraujoch, Izaña, and Wollongong where GEOSChem shows an overestimation of the methane increase.

We first discuss the possible causes of the slight trend discrepancy between FTIR observations at Jungfraujoch and Zugspitze as well as with GEOS-Chem for both stations. Indeed, despite their proximity $(\sim 250 \mathrm{~km}$ apart $)$ and their respective altitude of 3580 and $2954 \mathrm{~m}$, both Alpine sites show distinct influences from local thermal-induced vertical transport. At mountain-type sites, subsidence is predominant for anticyclonic weather conditions, resulting in adiabatic warming and cloud dissipation. The clear-sky and strong radiation conditions lead to the convective growth of the atmospheric boundary layer (ABL) and induce thermal injections of ABL air to the high-altitude observation sites (Collaud Coen et al., 2011; Henne et al., 2005; Nyeki et al., 2000). In addition, mountain venting induced by higher temperatures allows ABL air to be transported to the free troposphere, often occurring in summer (between April and Au- gust; Henne et al., 2005; Kreipl, 2006). While the Jungfraujoch site is a remote site, mostly influenced by free tropospheric air masses with incursions of ABL air masses during $50 \%$ of the spring and summer (Collaud Coen et al., 2011; Henne et al., 2005, 2010; Okamoto and Tanimoto, 2016; Zellweger et al., 2000, 2003), the Zugspitze site is more often influenced by the ABL (Henne et al., 2010). In summer, when the influence of the ABL is the largest, the observed changes are in very close agreement, with $0.25 \pm 0.06$ and $0.26 \pm 0.09 \%$ year $^{-1}$ respectively. Moreover, it has been established that vertical export of air masses above mountainous terrain is presently poorly represented in global CTMs (Henne et al., 2004). Mean annual changes of GEOS-Chem methane agree with the observations in summer during the influence of the ABL, with $0.33 \pm 0.04$ and $0.27 \pm 0.08 \%$ year $^{-1}$ for Jungfraujoch and Zugspitze respectively. In contrast, GEOS-Chem shows mean annual winter changes of $0.23 \pm 0.11$ and $0.19 \pm 0.09 \%$ year $^{-1}$ which agree with observed changes at Zugspitze but not with changes at Jungfraujoch. Since comparisons between FTIR measurements and GEOS-Chem methane show a disagreement on the methane changes during winter at Jungfraujoch, this seasonal analysis of changes of methane at mountainous observation sites emphasizes the current poorly modelled representation of summer versus winter thermal convection of air masses from the boundary layer to the free troposphere. 


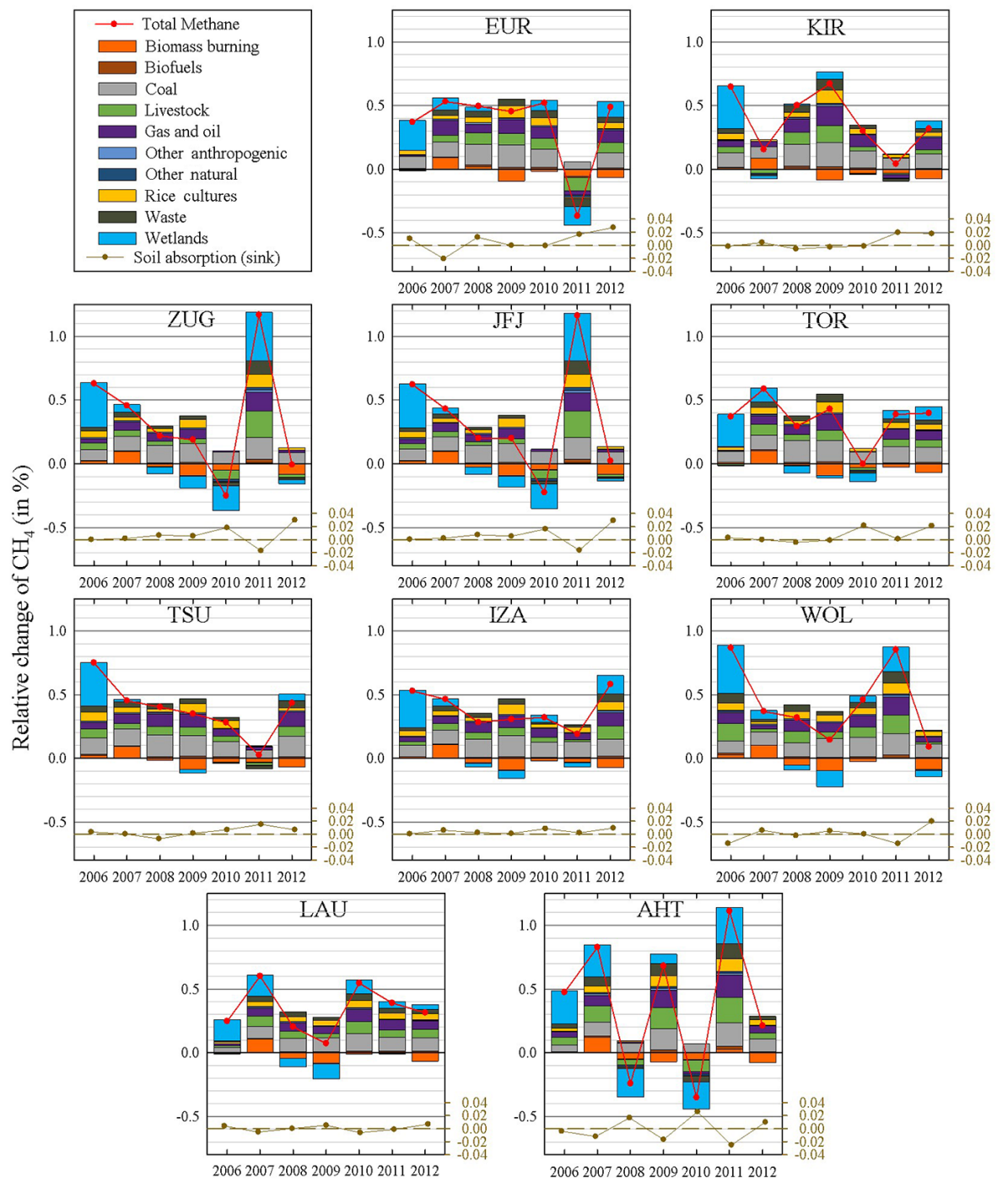

Figure 6. Year-to-year relative changes in $\mathrm{CH}_{4}$ total columns due to each emission source (see colour codes) for each station (see codes in Table 1) derived from GEOS-Chem. Brown circles represent the year-to-year relative changes of the methane sink due to soil absorption. Red circles illustrate the cumulative year-to-year methane change.

Regarding Izaña, it is worth mentioning that the FTIR methane total column time series shows a smaller seasonal cycle. Indeed, the combination of no local emission sources in the vicinity of Izaña, good mixing of air masses and a regular solar insolation associated with more constant $\mathrm{OH}$ amounts leads to a dampened seasonal cycle (Dlugokencky et al., 1994) at that site. Therefore, small annual changes of methane and smaller uncertainty on the mean annual change computed by the bootstrap method complicates the agreement between the FTIR and GEOS-Chem methane changes. However, as mentioned above, it should be pointed out that the amplitude of this smaller seasonal cycle is well reproduced by the GEOS-Chem simulation.

Regarding Wollongong, as already pointed out, noisier observations at the beginning of the period of interest may af- fect the relatively small annual changes of methane overall. In addition, one should not forget that sites such as Izaña or Wollongong can be challenging sites for models to reproduce due to the topography and land-sea contrast (Kulawik et al., 2016).

\subsubsection{Tagged simulation analysis}

The GEOS-Chem-tagged simulation, which provides the contribution of each tracer to the total simulated methane, enables us to quantify and express the contribution of each tracer to the global methane increase. In order to do so, we considered year-to-year relative changes according to the fol- 
lowing equation:

$Y C($ in $\%)=\frac{\left(\mu_{n}-\mu_{n-1}\right)}{\mu_{\mathrm{tot}, n-1}}$,

where $\mu_{n}$ is the annual mean of the simulated methane for the year $n$. The year-to-year relative changes are computed so that when we assume a relative change of a tracer for the year $n$, it is expressed with respect to the previous year ( $n-1)$ using $\mu_{\text {tot, } n-1}$ the annual mean of the simulated cumulative methane for the year $(n-1)$ as a reference. Averages of the individual relative year-to-year changes of total methane are in agreement with the mean annual change computed by the bootstrap method within error bars $(2 \sigma$ level uncertainty; Table 2). Therefore, the considered relative yearto-year changes of each tracer and for each site are illustrated in Fig. 6. The first three contributors to the annual methane change over the 2005-2012 time period are displayed for each site in Table B1 (see Appendix B) along with the cumulative relative increase for the whole 2005-2012 time period.

On a global scale, we observe from the tracer analysis as simulated by GEOS-Chem that natural emission sources such as emissions from wetlands and biomass burning fluctuate interannually, thus are the dominant contributors to the interannual variability in methane surface emissions. This is in agreement with the finding of Bousquet et al. (2011), who report that fluctuations in wetland emissions are the dominant contribution to interannual variability in surface emissions, explaining $70 \%$ of the global emission anomalies over the past 2 decades, while biomass burning contributes only $15 \%$. Regarding wetland emissions, the simulation shows a mean net increase of methane in 2006 of $+0.30 \%$ (mean value over all sites) attributed to the tracer. In 2007-2008, GEOS-Chem simulates a stabilization of methane in the atmosphere due to the reduction of wetland emissions. Indeed, we observe either a slightly negative change in wetland methane of $-0.08 \pm 0.07$ and of $-0.08 \pm 0.04 \%$ respectively in 2008 and 2009 (mean values over all sites) or a minor increase not larger than $0.07 \%$ in Arrival Heights (in 2009), in Tsukuba (in 2008) and in the high-latitude sites (i.e. Eureka and Kiruna in 2008 and 2009). On the other hand, the biomass burning tracer globally shows a net increase of $0.10 \pm 0.01 \%$ in 2007 likely due to the major fire season in tropical South America (Bloom et al., 2015) and a net decrease of $-0.09 \pm 0.01 \%$ in 2009 and of $-0.07 \pm 0.01 \%$ in 2012 with respect to the previous year. On the sink side, we find a negative phase between the relative year-to-year changes of the soil absorption tracer and the total methane simulated by GEOS-Chem except for Izaña where it remains positive over the time period studied.

On a local scale, we observe a slow-down of the increase in 2010 at midlatitude sites (i.e. Zugspitze, Jungfraujoch, Toronto) and in 2011 at Tsukuba and at the high-latitude sites of Eureka and Kiruna. Following this stabilization phase, European sites find a substantial increase of more than $1.15 \%$ in 2011 with respect to the previous year which is mainly due to an anomaly of wetlands emissions $(+0.38 \%)$ but also as a result of a relative increase of +0.21 and $+0.17 \%$ of emissions from livestock and coal. The Izaña site presents the most regular increase, mainly due to a smaller variability over the whole time period (seasonal cycle of Izaña previously discussed in Sect. 3.1.2.). In contrast, methane over Arrival Heights shows high variability from one year to another, which illustrates how dynamically sensitive the polar air is to transport from lower latitudes (Strahan et al., 2015).

Finally, regarding anthropogenic emissions, with positive year-to-year changes during the whole 2005-2012 time period, the coal and the gas and oil emissions both regularly increase over time. According to the GEOS-Chemtagged simulation, they rank as the most important anthropogenic contributors to methane changes for all stations (see Appendix B) and thus substantially contribute to the total methane increase. In fact, the coal and the gas and oil tracers respectively comprise a third (32\%) and almost a fifth (18\%) of the cumulative increase of methane over the 2005-2012 time period while their respective emissions are responsible for only 7.5 and $12.5 \%$ of the methane budget. As a comparison, the cumulative increase of methane emitted from wetlands amounts to $16 \%$ of the total increase since 2005, while wetland emissions make up $34 \%$ of the methane budget.

\section{Discussion and conclusions}

The cause of the methane increase since the mid-2000s has often been discussed and still has not been completely resolved (Aydin et al., 2011; Bloom et al., 2010; Dlugokencky et al., 2009; Hausmann et al., 2016; Kirschke et al., 2013; Nisbet et al., 2014; Rigby et al., 2008; Ringeval et al., 2010; Schaefer et al., 2016; Sussmann et al., 2012). On the sink side, Rigby et al. (2008) identified a decrease of $\mathrm{OH}$ radicals with a large uncertainty $(-4 \pm 14 \%)$ from 2006 to 2007 while Montzka et al. (2011) found a small drop of $\sim 1 \%$ year $^{-1}$, which might have contributed to the enhanced methane in the atmosphere. On the other hand, Bousquet et al. (2011) reported that the changes in $\mathrm{OH}$ remain small ( $<1 \%$ over the 2006-2008 time period). Nevertheless, observations of small interannual variations are in agreement with the understanding that perturbations in the atmospheric composition generally buffer the global $\mathrm{OH}$ concentrations (Dentener, 2003; Montzka et al., 2011).

The small to non-significant changes of methane in the stratosphere, as reported from the analysis of the ACEFTS methane research product, confirm that the increase of methane takes place in the troposphere. It is indeed driven by increasing sources emitted from the ground (Bousquet et al., 2011; Nisbet et al., 2014; Rigby et al., 2008), primarily affecting its tropospheric abundance and justifying the need for a source-oriented analysis of this recent increase.

Our analysis of the GEOS-Chem-tagged simulation determines that secondary contributors to the global budget 
of methane, such as coal mining and gas and oil transport and exploitation, have played a major role in the increase of atmospheric methane observed since 2005. However, while the simulation we used comprises the best emission inventories available so far, it has its limitations. Firstly, Schwietzke et al. (2014), Bergamaschi et al. (2013) and Bruhwiler et al. (2014) reported that the EDGAR v4.2 emission inventory overestimates the recent emission growth in Asia. Indeed, Turner et al. (2015) reported from a global GOSAT (Greenhouse gases Observing SATellite) inversion that Chinese methane emissions from coal mining are too large by a factor of 2 . Other regional discrepancies between the EDGAR v4.2 inventory and the GOSAT inversion such as an increase in wetland emissions in South America and an increase in rice emissions in South-east Asia, have been pointed out by Turner et al. (2015) as well. On the other hand, it has been shown that the current emissions inventories, including EDGAR v4.2, underestimate the emissions of methane associated with the gas and oil use and exploitation, as well as livestock emissions (Franco et al., 2015, 2016; Turner et al., 2015, 2016). Furthermore, Lyon et al. (2016) pointed out that emissions from oil and gas well pads may be missing from most bottom-up emission inventories. The problem of the source identification clearly resides in the need for a better characterization of anthropogenic emissions and especially in emissions of methane from the oil and gas and livestock sectors.

Concerning the oil and gas emissions, ethane has shown a sharp increase since 2009 of $\sim 5 \%$ year $^{-1}$ at midlatitudes and of $\sim 3 \%$ year $^{-1}$ at remote sites (Franco et al., 2016) which is attributed to the recent massive growth of oil and gas exploitation in the North American continent, with the geographical origin of these additional emissions confirmed by Helmig et al. (2016). Since ethane shares an anthropogenic source of methane, i.e. the production, transport and use of natural gas and the leakage associated to it (at $62 \%$; Logan et al., 1981; Rudolph, 1995), Franco et al. (2016) were able to estimate an increase of oil and gas methane emissions ranging from $20 \mathrm{Tg}_{\text {year }}{ }^{-1}$ in 2008 to $35 \mathrm{Tg}_{\text {year }}{ }^{-1}$ in 2014, using the $\mathrm{C}_{2} \mathrm{H}_{6} / \mathrm{CH}_{4}$ ratio derived from GOSAT measurements as a proxy, confirming the influence of fossil fuel and gas production emissions impact on the observed methane increase. Moreover, Hausmann et al. (2016) reported an oil and gas contribution to the renewed methane in Zugspitze of $39 \%$ over the 2007-2014 time period based on a $\mathrm{C}_{2} \mathrm{H}_{6} / \mathrm{CH}_{4}$ ratio derived from an atmospheric two-box model. However, as Kort et al. (2016) and Peischl et al. (2016) pointed out, the variability in the $\mathrm{C}_{2} \mathrm{H}_{6} / \mathrm{CH}_{4}$ ratio associated to oil and gas production needs to be taken into account in a more rigorous manner as the strength of the $\mathrm{C}_{2} \mathrm{H}_{6} / \mathrm{CH}_{4}$ relationship strongly depends on the studied region and/or production basin.

In conclusion, we report changes of atmospheric methane between 2005 and 2014 from FTIR measurements taken at 10 ground-based NDACC observation sites for the first time.
From the 10 NDACC methane time series, we computed a mean global annual increase of total column methane of $0.31 \pm 0.03 \%$ year $^{-1}$ (averaged over 10 stations, $2 \sigma$ level of uncertainty), using 2005.0 as reference, which is consistent with methane changes computed from in situ measurements. From the GEOS-Chem-tagged simulation, accounting for 11 tracers (10 emission sources and one sink) and covering the 2005-2012 time period, we computed a mean annual change of methane of $0.35 \pm 0.03 \%$ year $^{-1}$ since 2005 , which is globally in good agreement with the FTIR mean annual changes. In addition, we presented a detailed analysis of the GEOS-Chem tracer changes on both global and local scales over the 2005-2012 time period. To this end, we considered relative year-to-year changes in order to quantify the contribution of each tracer to the global methane change since 2005. According to the GEOS-Chem tagged simulation, wetland methane contributes mostly to the interannual variability while sources that contribute the most to the observed increase of methane since 2005 are mainly anthropogenic: coal mining, gas and oil exploitation, and livestock (from largest to smallest contribution). While we showed that GEOS-Chem agrees with our observations and consequently with the in situ measurements, the repartition between the different sources of methane would greatly benefit from an improvement of the global emission inventories. As an example, Turner et al. (2015) suggested that EDGAR v4.2 underestimates the US oil and gas and livestock emissions while overestimating methane emissions associated to coal mining. From the emission source shared by both ethane and methane and from various ethane studies, it is clear that further attention has to be given to improved anthropogenic methane inventories, such as emission inventories associated with fossil fuel and natural gas production. This is essential in a context of the energy transition that includes the development of shale gas exploitation.

Finally, it is worth mentioning that Schaefer et al. (2016) argue with the fact that thermogenic emissions of methane are responsible for the renewed increase of methane during the mid-2000s. Indeed, from methane isotopologue observations and a one-box model deriving global emission strength and isotopic source signature, Schaefer et al. (2016) reports that the recent methane increase is predominantly due to biogenic emission sources such as agriculture and climatesensitive natural emissions. These results contrast with the context of a booming natural gas production and the resumption of coal mining in Asia. However, it is also worth noting that the ${ }^{13} \mathrm{C} /{ }^{12} \mathrm{C}$ and $\mathrm{D} / \mathrm{H}$ ratio of atmospheric methane show distinctive isotope signature depending on the source type (Bergamaschi, 1997; Bergamaschi et al., 1998; Quay et al., 1999; Snover et al., 2000; Whiticar and Schaefer, 2007). In the same way, isotopic fractionation occurs during sink processes with specific ratios depending on the removal pathway (Gierczak et al., 1997; Irion et al., 1996; Saueressig et al., 2001; Snover and Quay, 2000; Tyler et al., 2000). Therefore, the underexploited analysis of the recent methane in- 
crease through trend analysis of methane isotopologues, such as ${ }^{13} \mathrm{CH}_{4}$ and $\mathrm{CH}_{3} \mathrm{D}$, is an innovative way of addressing the question of the source(s) responsible for the recent methane increase.

\section{Data availability}

Most of the data used in this publication were obtained as part of the Network for the Detection of Atmospheric Composition Change (NDACC) and are publicly available (see http://www.ndacc.org). Time series used to produce Fig. 5, as well as GEOS-Chem-tagged simulation time series, can be found on the University of Liège's repository (see http: //orbi.ulg.ac.be/handle/2268/207090). In situ surface measurements taken in the framework of the NOAA ESRL carbon cycle air sampling network (Dlugokencky et al., 2015; version: 2015-08-03; date accessed: 9 May 2016) are available at ftp://aftp.cmdl.noaa.gov/data/trace_gases/ch4/flask/ surface/. Surface GC-MD observations carried out in the framework of the AGAGE programme (Prinn et al., 2000; date accessed: 9 May 2016) are available at http://agage.eas. gatech.edu/data_archive/agage/gc-md/. 


\section{Appendix A: NDACC FTIR retrieval strategies}

Table A1 summarizes the retrieval parameters for methane for each station. FTIR measurements are analysed as recommended either by Rinsland et al. (2006), Sussmann et al. (2011), or Sepúlveda et al. (2012). The spectral microwindows limits for the Eureka, Zugspitze, Toronto and Wollongong stations are based on Sussmann et al. (2011) and use the Hitran-2000 spectroscopic database including the release of the 2001 update (Rothman et al., 2003) except for Toronto where Hitran 2008 was employed (Rothman et al., 2009). The microwindows used for the Kiruna, Jungfraujoch, Izaña observations are based on Sepulveda et al. (2012). For all interfering species, Hitran 2008 parameters are used. For methane, ad hoc adjustments carried out by KIT, IMK-ASF are used (D. Dubravica, personal communication, December 2012; see also Dubravica et al., 2013). Finally, the microwindows used for the Lauder and Arrival Heights observations are based on Rinsland et al. (2006). In order to better appraise the relatively low humidity rates at Jungfraujoch, a prefitting of the two microwindows (2611.60-2613.35 and 2941.65-2941.89) dedicated to water vapour and its isotopologue HDO is performed and used as a priori for the actual retrieval.

A priori profiles for target and interfering molecules are based on the Whole Atmosphere Community Climate Model (version 5 or 6, WACCM, e.g. Chang et al., 2008) climatology, except for Tsukuba, Lauder, and Arrival Heights. A priori profiles for Tsukuba retrievals include monthly averaged profiles made from aeroplane measurements over Japan by the National Institute of Environmental Studies, Japan (NIES, http://www.nies.go.jp/index-e.html). A priori profiles for Lauder retrieval include annual mean of measurements from the Microwave Limb Sounder (MLS, https: $/ / \mathrm{mls}$.jpl.nasa.gov/) and the Halogen Occultation Experiment (HALOE, http://haloe.gats-inc.com/home/index.php) on board the Upper Atmosphere Research Satellite (UARS, http://uars.gsfc.nasa.gov/) at $44^{\circ} \mathrm{S}$ in the framework of the UARS Reference Atmosphere Project (URAP, Grooß and Russell, 2005). A priori profiles for Arrival Heights retrievals include the zonal mean of measurements from the Atmospheric Trace Molecule Spectroscopy Experiment (ATMOS) Spacelab 3 over the $14-65 \mathrm{~km}$ altitude range (Gunson et al., 1996). As mentioned in the Sect. 2.2.2. of this paper, a Tikhonov regularization (Tikhonov, 1963) is used and optimized in order to limit the value of the degrees of freedom for signal (DOFS) to a value of approximately 2 (Sussmann et al., 2011) except for Lauder and Arrival Heights which use an optimal estimation method (OEM) based on the formalism of Rodgers (1990). Averaged DOFS value and associated $1 \sigma$ uncertainty are given in the last column of Table A1. 
Table A1. Retrieval parameters for each station.

\begin{tabular}{|c|c|c|c|c|c|c|}
\hline Station & $\begin{array}{l}\text { Retrieval } \\
\text { code }\end{array}$ & $\begin{array}{l}\text { Retrieval } \\
\text { windows }\left(\mathrm{cm}^{-1}\right)\end{array}$ & Interfering gases & $\begin{array}{l}\text { A priori and } \\
\text { regularization }\end{array}$ & Linelist & $\begin{array}{l}\text { Averaged } \\
\text { DOFS }\end{array}$ \\
\hline EUR & SFIT-4 & $\begin{array}{l}2613.7-2615.4 \\
2835.5-2835.8 \\
2921.0-2921.6\end{array}$ & $\begin{array}{l}\mathrm{HDO} \mathrm{CO} \\
\mathrm{HDO} \\
\mathrm{HDO} \mathrm{H}_{2} \mathrm{O} \mathrm{NO}_{2}\end{array}$ & $\begin{array}{l}\text { WACCM v6 } \\
\text { Tikhonov } \mathrm{L}_{1}\end{array}$ & HIT-08 & $2.31 \pm 0.66$ \\
\hline KIR & PROFFIT & $\begin{array}{l}2611.6-2613.35 \\
2613.7-2615.4 \\
2835.55-2835.8 \\
2903.82-2903.925 \\
2914.7-2915.15 \\
2941.51-2942.22\end{array}$ & 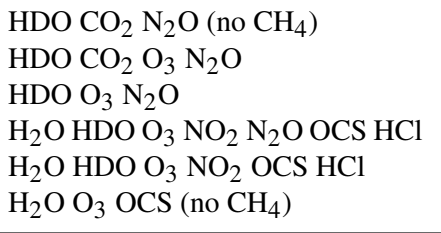 & $\begin{array}{l}\text { WACCM v6 } \\
\text { Tikhonov } \mathrm{L}_{1}\end{array}$ & $\begin{array}{l}\text { ad hoc } \mathrm{CH}_{4} \\
\text { HIT-08 }\end{array}$ & $2.35 \pm 0.29$ \\
\hline ZUG & PROFFIT & $\begin{array}{l}2613.7-2615.4 \\
2835.5-2835.8 \\
2921.0-2921.6\end{array}$ & $\begin{array}{l}\mathrm{HDO} \mathrm{CO} \\
\mathrm{HDO} \\
\mathrm{HDO} \mathrm{H}_{2} \mathrm{O} \mathrm{NO}_{2}\end{array}$ & $\begin{array}{l}\text { WACCM v6 } \\
\text { Tikhonov } \mathrm{L}_{1}\end{array}$ & HIT-00 & $1.93 \pm 0.32$ \\
\hline JFJ & $\begin{array}{l}\text { SFIT-2 } \\
\text { v3.94 }\end{array}$ & $\begin{array}{l}2611.60-2613.35 \\
2613.7-2615.4 \\
2835.55-2835.80 \\
2903.82-2903.925 \\
2914.70-2915.15 \\
2941.65-2941.89\end{array}$ & $\begin{array}{l}\mathrm{HDO} \mathrm{CO}\left(\mathrm{no} \mathrm{CH}_{4}\right) \\
\mathrm{HDO} \mathrm{CO} \mathrm{O}_{3} \\
\mathrm{HDO} \mathrm{O} \\
\mathrm{H}_{2} \mathrm{O} \mathrm{HDO} \mathrm{O} \mathrm{ONO}_{2} \mathrm{NO}_{2} \\
\mathrm{H}_{2} \mathrm{O} \mathrm{HDO} \mathrm{O}_{3} \mathrm{NO}_{2} \mathrm{HCl} \\
\mathrm{H}_{2} \mathrm{O} \mathrm{O}_{3}\left(\mathrm{no}_{4} \mathrm{CH}_{4}\right)\end{array}$ & $\begin{array}{l}\text { WACCM v6 } \\
\text { Tikhonov } \mathrm{L}_{1}\end{array}$ & $\begin{array}{l}\text { ad hoc } \mathrm{CH}_{4} \\
\text { HIT- } 08\end{array}$ & $2.37 \pm 0.46$ \\
\hline TOR & SFIT-4 & $\begin{array}{l}2613.7-2615.4 \\
2835.5-2835.8 \\
2921.0-2921.6\end{array}$ & $\begin{array}{l}\mathrm{HDO} \mathrm{CO} 2 \\
\mathrm{HDO} \\
\mathrm{HDO} \mathrm{H}_{2} \mathrm{O} \mathrm{NO}_{2}\end{array}$ & $\begin{array}{l}\text { WACCM v6 } \\
\text { Tikhonov } \mathrm{L}_{1}\end{array}$ & HIT-08 & $2.05 \pm 0.69$ \\
\hline TSU & $\begin{array}{l}\text { SFIT-2 } \\
\text { v3.94 }\end{array}$ & $\begin{array}{l}2613.7-2615.4 \\
2835.5-2835.8 \\
2921.0-2921.6\end{array}$ & $\begin{array}{l}\mathrm{HDO} \mathrm{CO} 2 \\
\mathrm{HDO} \\
\mathrm{HDO} \mathrm{H}_{2} \mathrm{O} \mathrm{NO}_{2}\end{array}$ & $\begin{array}{l}\text { NIES Airplane } \\
\text { Tikhonov } \mathrm{L}_{1}\end{array}$ & HIT-00 & $2.73 \pm 0.18$ \\
\hline IZA & PROFFIT & $\begin{array}{l}2611.6-2613.35 \\
2613.7-2615.4 \\
2835.55-2835.8 \\
2903.82-2903.925 \\
2914.7-2915.15 \\
2941.51-2942.22 \\
\end{array}$ & $\begin{array}{l}\mathrm{HDO} \mathrm{CO} \mathrm{N}_{2} \mathrm{O}\left(\mathrm{no} \mathrm{CH}_{4}\right) \\
\mathrm{HDO} \mathrm{CO} \mathrm{O}_{3} \mathrm{~N}_{2} \mathrm{O} \\
\mathrm{HDO} \mathrm{O} \mathrm{N}_{2} \mathrm{O} \\
\mathrm{H}_{2} \mathrm{O} \mathrm{HDO} \mathrm{O}_{3} \mathrm{NO}_{2} \mathrm{~N}_{2} \mathrm{O} \text { OCS HCl } \\
\mathrm{H}_{2} \mathrm{O} \mathrm{HDO} \mathrm{O}_{3} \mathrm{NO}_{2} \mathrm{OCS} \mathrm{HCl} \\
\mathrm{H}_{2} \mathrm{O} \mathrm{O}_{3} \mathrm{OCS}\left(\mathrm{no} \mathrm{CH}_{4}\right)\end{array}$ & $\begin{array}{l}\text { WACCM v6 } \\
\text { Tikhonov } \mathrm{L}_{1}\end{array}$ & $\begin{array}{l}\text { ad hoc } \mathrm{CH}_{4} \\
\text { HIT- } 08\end{array}$ & $2.42 \pm 0.28$ \\
\hline WOL & $\begin{array}{l}\text { SFIT-2 } \\
\text { v3.94 }\end{array}$ & $\begin{array}{l}2613.7-2615.4 \\
2835.5-2835.8 \\
2921.0-2921.6 \\
\end{array}$ & $\begin{array}{l}\mathrm{HDO} \mathrm{CO} \\
\mathrm{HDO} \\
\mathrm{HDO} \mathrm{H}_{2} \mathrm{O} \mathrm{NO}_{2}\end{array}$ & $\begin{array}{l}\text { WACCM v5 } \\
\text { Tikhonov } \mathrm{L}_{1}\end{array}$ & HIT-00 & $1.81 \pm 0.28$ \\
\hline LAU & $\begin{array}{l}\text { SFIT-2 } \\
\text { v3.82 }\end{array}$ & $\begin{array}{l}2650.85-2651.25 \\
2666.95-2667.35 \\
2673.90-2674.41\end{array}$ & $\begin{array}{l}\text { HDO } \\
\text { HDO } \\
\text { HDO }\end{array}$ & $\begin{array}{l}\text { URAP at } 44^{\circ} \mathrm{S} \\
\text { OEM }\end{array}$ & HIT-00 & $2.96 \pm 0.73$ \\
\hline AHT & $\begin{array}{l}\text { SFIT-2 } \\
\text { v3.82 }\end{array}$ & $\begin{array}{l}2650.85-2651.25 \\
2666.95-2667.35 \\
2673.90-2674.41\end{array}$ & $\begin{array}{l}\text { HDO } \\
\text { HDO } \\
\text { HDO }\end{array}$ & $\begin{array}{l}\text { ATMOS } \\
\text { zonal mean } \\
\text { OEM }\end{array}$ & HIT-00 & $3.54 \pm 0.76$ \\
\hline
\end{tabular}


Appendix B: Top three contributors to the methane increase as simulated by GEOS-Chem

Table B1 illustrates the first three contributors to the annual methane change and their year-to-year changes for each site along with the cumulative relative increase for the whole 2005-2012 time period. The GEOS-Chem tracers are coded as follows: biomass burning (bb), biofuels (bf), coal (co), livestock (li), gas and oil (ga), other anthropogenic sources (oa), other natural sources (on), rice cultivation (ri), waste management (wa), wetlands (wl).

Table B1. Top three simulated tracers contributing the most to the methane changes, per year, and per site, in $\%$.

\begin{tabular}{|c|c|c|c|c|c|c|c|c|c|c|c|c|c|c|c|c|c|}
\hline \multirow{2}{*}{$\begin{array}{l}\text { Station } \\
\text { EUR }\end{array}$} & \multirow{2}{*}{$\begin{array}{l}\% \\
\text { tracers }\end{array}$} & \multicolumn{2}{|c|}{$2005-2006$} & \multicolumn{2}{|c|}{$2006-2007$} & \multicolumn{2}{|c|}{$2007-2008$} & \multicolumn{2}{|c|}{$2008-2009$} & \multicolumn{2}{|c|}{ 2009-2010 } & \multicolumn{2}{|c|}{$2010-2011$} & \multicolumn{2}{|c|}{ 2011-2012 } & \multicolumn{2}{|c|}{ 2005-2012 } \\
\hline & & wl & 0.23 & co & 0.12 & co & 0.16 & co & 0.17 & co & 0.14 & wl & -0.15 & wl & 0.12 & co & 0.87 \\
\hline & & co & 0.10 & ga & 0.12 & li & 0.09 & ga & 0.11 & ga & 0.11 & li & -0.11 & co & 0.12 & ga & 0.46 \\
\hline & & ri & 0.03 & $\mathrm{bb}$ & 0.09 & ga & 0.07 & ri & 0.09 & ri & 0.09 & wa & -0.06 & ga & 0.09 & wl & 0.42 \\
\hline & total & & 0.37 & & 0.53 & & 0.49 & & 0.45 & & 52 & & 0.37 & & 0.49 & & .49 \\
\hline \multirow[t]{4}{*}{ KIR } & tracers & wl & 0.34 & co & 0.34 & co & 0.17 & co & 0.19 & co & 0.13 & co & 0.09 & co & 0.11 & co & 0.98 \\
\hline & & co & 0.11 & $\mathrm{bb}$ & 0.11 & ga & 0.10 & ga & 0.15 & ga & 0.09 & bb & -0.03 & ga & 0.10 & ga & 0.51 \\
\hline & & ga & 0.05 & ga & 0.05 & $\mathrm{li}$ & 0.09 & ri & 0.17 & ri & 0.04 & ga & -0.03 & wl & 0.06 & wl & 0.44 \\
\hline & total & & 0.65 & & 0.15 & & 0.50 & & 0.67 & & 30 & & .04 & & 0.32 & & 63 \\
\hline \multirow[t]{4}{*}{ ZUG } & tracers & wl & 0.35 & co & 0.11 & co & 0.14 & co & 0.15 & wl & -0.20 & wl & 0.38 & co & 0.09 & co & 0.83 \\
\hline & & co & 0.09 & $\mathrm{bb}$ & 0.10 & ga & 0.06 & ga & 0.08 & li & -0.07 & li & 0.21 & $\mathrm{bb}$ & -0.08 & wl & 0.42 \\
\hline & & $\mathrm{ri}$ & 0.05 & ga & 0.07 & $\mathrm{li}$ & 0.03 & ri & 0.07 & $\mathrm{bb}$ & -0.05 & co & 0.17 & sa & 0.03 & ga & 0.41 \\
\hline & total & & 0.63 & & 0.46 & & 0.22 & & 0.19 & & 0.25 & & .17 & & -0.01 & & .40 \\
\hline \multirow[t]{4}{*}{$\mathrm{JFJ}$} & tracers & wl & 0.35 & co & 0.11 & co & 0.14 & co & 0.15 & wl & -0.19 & wl & 0.38 & wl & 0.38 & co & 0.09 \\
\hline & & co & 0.11 & $\mathrm{bb}$ & 0.10 & ga & 0.06 & ga & 0.08 & li & -0.06 & li & 0.21 & li & 0.21 & $\mathrm{bb}$ & -0.08 \\
\hline & & ri & 0.05 & ga & 0.06 & li & 0.03 & ri & 0.07 & $\mathrm{bb}$ & -0.05 & co & 0.17 & $\mathrm{co}$ & 0.17 & sa & -0.03 \\
\hline & total & & 0.62 & & 0.43 & & 0.20 & & 0.20 & & 0.22 & & .16 & & 1.16 & & .41 \\
\hline \multirow[t]{4}{*}{ TOR } & tracers & wl & 0.26 & co & 0.12 & co & 0.17 & $\mathrm{co}$ & 0.17 & co & 0.09 & $\mathrm{co}$ & 0.13 & $\mathrm{co}$ & 0.12 & $\mathrm{co}$ & 0.87 \\
\hline & & co & 0.09 & wl & 0.11 & ga & 0.07 & ga & 0.17 & wl & -0.06 & ga & 0.08 & wl & 0.10 & ga & 0.43 \\
\hline & & ri & 0.03 & $\mathrm{bb}$ & 0.10 & li & 0.05 & ri & 0.08 & $\mathrm{bb}$ & -0.03 & wl & 0.06 & ga & 0.07 & wl & 0.40 \\
\hline & total & & 0.37 & & 0.59 & & 0.29 & & 0.43 & & .00 & & .39 & & 0.40 & & .46 \\
\hline \multirow[t]{4}{*}{ TSU } & tracers & wl & 0.34 & co & 0.13 & co & 0.17 & co & 0.16 & co & 0.12 & co & 0.06 & co & 0.16 & co & 0.94 \\
\hline & & co & 0.13 & $\mathrm{bb}$ & 0.09 & ga & 0.10 & ga & 0.10 & ri & 0.06 & ga & 0.02 & ga & 0.11 & ga & 0.52 \\
\hline & & li & 0.07 & ga & 0.07 & $\mathrm{li}$ & 0.07 & ri & 0.07 & ga & 0.05 & $\mathrm{bb}$ & -0.03 & li & 0.08 & wl & 0.39 \\
\hline & total & & 0.75 & & 0.45 & & 0.40 & & 0.35 & & 28 & & .03 & & 0.43 & & .69 \\
\hline \multirow[t]{4}{*}{ IZA } & tracers & wl & 0.30 & co & 0.11 & co & 0.14 & co & 0.16 & co & 0.12 & co & 0.12 & wl & 0.15 & co & 0.87 \\
\hline & & co & 0.09 & $\mathrm{bb}$ & 0.11 & ga & 0.08 & ga & 0.10 & ga & 0.07 & ga & 0.07 & co & 0.13 & ga & 0.49 \\
\hline & & ri & 0.04 & wl & 0.06 & li & 0.05 & ri & 0.08 & wl & 0.06 & ri & 0.04 & li & 0.11 & wl & 0.15 \\
\hline & total & & 0.53 & & 0.46 & & 0.28 & & 0.31 & & 32 & & .19 & & 0.58 & & .67 \\
\hline \multirow[t]{4}{*}{ WOL } & tracers & wl & 0.38 & $\mathrm{bb}$ & 0.10 & co & 0.11 & co & 0.15 & co & 0.15 & wl & 0.19 & $\mathrm{co}$ & 0.10 & co & 0.78 \\
\hline & & li & 0.14 & co & 0.10 & li & 0.09 & ga & 0.07 & ga & 0.09 & co & 0.17 & $\mathrm{bb}$ & -0.09 & li & 0.52 \\
\hline & & $\mathrm{co}$ & 0.09 & wl & 0.07 & ga & 0.09 & ri & 0.06 & li & 0.08 & li & 0.15 & ga & 0.04 & ga & 0.51 \\
\hline & total & & 0.87 & & 0.37 & & 0.32 & & 0.14 & & 46 & & .85 & & 0.09 & & .01 \\
\hline \multirow[t]{4}{*}{ LAU } & tracers & wl & 0.17 & wl & 0.17 & co & 0.10 & co & 0.11 & co & 0.13 & co & 0.11 & $\mathrm{co}$ & 0.10 & $\mathrm{ca}$ & 0.70 \\
\hline & & co & 0.04 & bb & 0.11 & ga & 0.06 & ga & 0.06 & wl & 0.11 & ga & 0.08 & ga & 0.07 & ga & 0.43 \\
\hline & & ri & 0.02 & co & 0.09 & li & 0.06 & wl & -0.12 & li & 0.10 & li & 0.05 & li & 0.07 & li & 0.41 \\
\hline & total & & 0.25 & & 0.60 & & 0.20 & & 0.07 & & 55 & & .39 & & 0.31 & & .37 \\
\hline \multirow[t]{4}{*}{ AHT } & tracers & wl & 0.26 & wl & 0.25 & wl & -0.22 & li & 0.17 & wl & -0.21 & wl & 0.29 & co & 0.10 & co & 0.75 \\
\hline & & li & 0.06 & li & 0.13 & $\mathrm{bb}$ & -0.05 & co & 0.17 & li & -0.09 & li & 0.20 & ga & 0.06 & ga & 0.48 \\
\hline & & $\mathrm{co}$ & 0.05 & $\mathrm{bb}$ & 0.12 & co & 0.07 & ga & 0.14 & co & 0.07 & co & 0.18 & li & 0.04 & li & 0.47 \\
\hline & total & & 0.47 & & 0.83 & & 0.24 & & 0.68 & & 0.35 & & .11 & & 0.21 & & .71 \\
\hline
\end{tabular}


Competing interests. The authors declare that they have no conflict of interest.

Acknowledgements. W. Bader has received funding from the European Union's Horizon 2020 research and innovation programme under the Marie Sklodowska-Curie grant agreement no. 704951, and from the University of Toronto through a Faculty of Arts \& Science Postdoctoral Fellowship Award. The University of Liège's involvement has primarily been supported by the PRODEX and SSD programmes funded by the Belgian Federal Science Policy Office (Belspo), Brussels. The Swiss GAW-CH programme is further acknowledged. E. Mahieu is a Research Associate with the F.R.S.-FNRS. The F.R.S.-FNRS further supported this work under Grant no. J.0093.15 and the Fédération Wallonie Bruxelles contributed to supporting observational activities. We thank O. Flock for his constant support during this research. We thank the International Foundation High Altitude Research Stations Jungfraujoch and Gornergrat (HFSJG, Bern) for supporting the facilities needed to perform the observations. The Eureka measurements were made at the Polar Environment Atmospheric Research Laboratory (PEARL) by the Canadian Network for the Detection of Atmospheric Change (CANDAC), led by James R. Drummond and in part by the Canadian Arctic ACE/OSIRIS Validation Campaigns, led by Kaley A. Walker. They were supported by the AIF/NSRIT, CFI, CFCAS, CSA, EC, GOC-IPY, NSERC, NSTP, OIT, PCSP, and ORF. Logistical and operational support at Eureka is provided by PEARL Site Manager Pierre Fogal, CANDAC operators, and the EC Weather Station. The Toronto measurements were made at the University of Toronto Atmospheric Observatory (TAO), which has been supported by CFCAS, ABB Bomem, CFI, CSA, EC, NSERC, ORDCF, PREA, and the University of Toronto. We also thank the CANDAC operators, and the many students, postdocs, and interns who have contributed to data acquisition at Eureka and Toronto. Analysis of the Eureka and Toronto NDACC data was supported by the CAFTON project, funded by the Canadian Space Agency's FAST Program. KIT, IMK-ASF would like to thank Uwe Raffalski and Peter Voelgel from the Swedish Institute of Space Physics (IRF) for their continuing support of the NDACC-FTIR site Kiruna. KIT, IMK-ASF would also like to thank E. Sepúlveda for the support in carrying out the FTIR measurements at Izaña. Garmisch work has been performed as part of the ESA GHG-cci project, and KIT, IMK-IFU acknowledge funding by the EC within the INGOS project. The Centre for Atmospheric Chemistry at the University of Wollongong involvement in this work is funded by Australian Research Council projects DP1601021598 and LE0668470. Measurements and analysis conducted at Lauder, New Zealand and Arrival Heights, Antarctica are supported by NIWA as part of its government-funded, core research. We thank Antarctica New Zealand for logistical support for the measurements taken at Arrival Heights. A. J. Turner was supported by a Department of Energy (DOE) Computational Science Graduate Fellowship (CSGF). The ACE mission is supported primarily by the Canadian Space Agency. AGAGE is supported principally by NASA (USA) grants to MIT and SIO, and also by DECC (UK) and NOAA (USA) grants to Bristol University and by CSIRO and the Bureau of Meteorology (Australia). We further thank NOAA for providing in situ data for Alert, Izaña and Halley.
Edited by: H. Maring

Reviewed by: three anonymous referees

\section{References}

Aydin, M., Verhulst, K. R., Saltzman, E. S., Battle, M. O., Montzka, S. A., Blake, D. R., Tang, Q.. and Prather, M. J.: Recent decreases in fossil-fuel emissions of ethane and methane derived from firn air. Nature, 476, 198-201, doi:10.1038/nature10352, 2011.

Batchelor, R. L., Strong, K., Lindenmaier, R., Mittermeier, R. L., Fast, H., Drummond, J. R., and Fogal, P. F.: A New Bruker IFS 125HR FTIR Spectrometer for the Polar Environment Atmospheric Research Laboratory at Eureka, Nunavut, Canada: Measurements and Comparison with the Existing Bomem DA8 Spectrometer, J. Atmos. Ocean. Tech., 26, 1328-1340, doi:10.1175/2009JTECHA1215.1, 2009.

Bergamaschi, P.: Seasonal variations of stable hydrogen and carbon isotope ratios in methane from a Chinese rice paddy, J. Geophys. Res., 102, 25383-25393, doi:10.1029/97JD01664, 1997.

Bergamaschi, P., Lubina, C., Königstedt, R., Fischer, H., Veltkamp, A. C., and Zwaagstra, O.: Stable isotopic signatures $\left(\delta^{13} \mathrm{C}, \delta \mathrm{D}\right)$ of methane from European landfill sites, J. Geophys. Res., 103, 8251-8265, 1998.

Bergamaschi, P., Houweling, S., Segers, A., Krol, M., Frankenberg, C., Scheepmaker, R. A., Dlugokencky, E., Wofsy, S. C., Kort, E. A., Sweeney, C., Schuck, T., Brenninkmeijer, C., Chen, H., Beck, V., and Gerbig, C.: Atmospheric $\mathrm{CH}_{4}$ in the first decade of the 21 st century: Inverse modeling analysis using SCIAMACHY satellite retrievals and NOAA surface measurements, J. Geophys. Res.-Atmos., 118, 7350-7369, doi:10.1002/jgrd.50480, 2013.

Bernath, P. F., McElroy, C. T., Abrams, M. C., Boone, C. D., Butler, M., Camy-Peyret, C., Carleer, M., Clerbaux, C., Coheur, P.-F., Colin, R., DeCola, P., DeMazière, M., Drummond, J. R., Dufour, D., Evans, W. F. J., Fast, H., Fussen, D., Gilbert, K., Jennings, D. E., Llewellyn, E. J., Lowe, R. P., Mahieu, E., McConnell, J. C., McHugh, M., McLeod, S. D., Michaud, R., Midwinter, C., Nassar, R., Nichitiu, F., Nowlan, C., Rinsland, C. P., Rochon, Y. J., Rowlands, N., Semeniuk, K., Simon, P., Skelton, R., Sloan, J. J., Soucy, M.-A., Strong, K., Tremblay, P., Turnbull, D., Walker, K. A., Walkty, I., Wardle, D. A., Wehrle, V., Zander, R. and Zou, J.: Atmospheric Chemistry Experiment (ACE): Mission overview, Geophys. Res. Lett., 32, L15S01, doi:10.1029/2005GL022386, 2005.

Bloom, A. A., Palmer, P. I., Fraser, A., Reay, D. S., and Frankenberg, C.: Large-Scale Controls of Methanogenesis Inferred from Methane and Gravity Spaceborne Data, Science, 327, 322-325, doi:10.1126/science.1175176, 2010.

Bloom, A. A., Worden, J., Jiang, Z., Worden, H., Kurosu, T., Frankenberg, C., and Schimel, D.: Remote-sensing constraints on South America fire traits by Bayesian fusion of atmospheric and surface data, Geophys. Res. Lett., 42, 1268-1274, doi:10.1002/2014GL062584, 2015.

Bousquet, P., Ciais, P., Miller, J. B., Dlugokencky, E. J., Hauglustaine, D. A., Prigent, C., Van der Werf, G. R., Peylin, P., Brunke, E.-G., Carouge, C., Langenfelds, R. L., Lathiere, J., Papa, F., Ramonet, M., Schmidt, M., Steele, L. P., Tyler, S. C., and White, J.: Contribution of anthropogenic and natural sources to atmospheric methane variability, Nature, 443, 439-443, 2006. 
Bousquet, P., Ringeval, B., Pison, I., Dlugokencky, E. J., Brunke, E.G., Carouge, C., Chevallier, F., Fortems-Cheiney, A., Frankenberg, C., Hauglustaine, D. A., Krummel, P. B., Langenfelds, R. L., Ramonet, M., Schmidt, M., Steele, L. P., Szopa, S., Yver, C., Viovy, N., and Ciais, P.: Source attribution of the changes in atmospheric methane for 2006-2008, Atmos. Chem. Phys., 11, 3689-3700, doi:10.5194/acp-11-3689-2011, 2011.

Bruhwiler, L., Dlugokencky, E., Masarie, K., Ishizawa, M., Andrews, A., Miller, J., Sweeney, C., Tans, P., and Worthy, D.: CarbonTracker- $\mathrm{CH}_{4}$ : an assimilation system for estimating emissions of atmospheric methane, Atmos. Chem. Phys., 14, 82698293, doi:10.5194/acp-14-8269-2014, 2014.

Buzan, E. M., Beale, C. A., Boone, C. D., and Bernath, P. F.: Global stratospheric measurements of the isotopologues of methane from the Atmospheric Chemistry Experiment Fourier transform spectrometer, Atmos. Meas. Tech., 9, 1095-1111, doi:10.5194/amt-9-1095-2016, 2016.

Chang, L., Palo, S., Hagan, M., Richter, J., Garcia, R., Riggin, D., and Fritts, D.: Structure of the migrating diurnal tide in the Whole Atmosphere Community Climate Model (WACCM), Adv. Sp. Res., 41, 1398-1407, doi:10.1016/j.asr.2007.03.035, 2008.

Chen, Y.-H. and Prinn, R. G.: Estimation of atmospheric methane emissions between 1996 and 2001 using a three-dimensional global chemical transport model, J. Geophys. Res.-Atmos., 111, D10307, doi:10.1029/2005JD006058, 2006.

Collaud Coen, M., Weingartner, E., Furger, M., Nyeki, S., Prévôt, A. S. H., Steinbacher, M., and Baltensperger, U.: Aerosol climatology and planetary boundary influence at the Jungfraujoch analyzed by synoptic weather types, Atmos. Chem. Phys., 11, 5931-5944, doi:10.5194/acp-11-5931-2011, 2011.

Cox, C. J., Walden, V. P., and Rowe, P. M.: A comparison of the atmospheric conditions at Eureka, Canada, and Barrow, Alaska (2006-2008), J. Geophys. Res.-Atmos., 117, D12204, doi:10.1029/2011JD017164, 2012.

Dentener, F.: Interannual variability and trend of $\mathrm{CH}_{4}$ lifetime as a measure for OH changes in the 1979-1993 time period, J. Geophys. Res., 108, 4442, doi:10.1029/2002JD002916, 2003.

Dlugokencky, E. J.: Atmospheric methane levels off: Temporary pause or a new steady-state?, Geophys. Res. Lett., 30, 1992, doi:10.1029/2003GL018126, 2003.

Dlugokencky, E. J., Steele, L. P., Lang, P. M., and Masarie, K. A.: The growth rate and distribution of atmospheric methane, J. Geophys. Res., 99, 17021, doi:10.1029/94JD01245, 1994.

Dlugokencky, E. J., Bruhwiler, L., White, J. W. C., Emmons, L. K., Novelli, P. C., Montzka, S. A., Masarie, K. a., Lang, P. M., Crotwell, A. M., Miller, J. B., and Gatti, L. V.: Observational constraints on recent increases in the atmospheric $\mathrm{CH}_{4}$ burden, Geophys. Res. Lett., 36, L18803, doi:10.1029/2009GL039780, 2009.

Dlugokencky, E. J., Lang, P. M., Crotwell, A. M., Masarie, K. A., Crotwell, M. J., and Thoning, K. W.: Atmospheric methane dry air mole fractions from the NOAA ESRL carbon cycle cooperative global air sampling network, 1983-2015, Version: 2015-0803, available at: ftp://aftp.cmdl.noaa.gov/data/trace_gases/ch4/ flask/surface/ (last access: 9 May 2016), 2015.

van Donkelaar, A., Martin, R. V., Pasch, A. N., Szykman, J. J., Zhang, L., Wang, Y. X., and Chen, D.: Improving the Accuracy of Daily Satellite-Derived Ground-Level Fine Aerosol Concen- tration Estimates for North America, Environ. Sci. Technol., 46, 11971-11978, doi:10.1021/es3025319, 2012.

Dubravica, D., Birk, M., Hase, F., Loos, J., Palm, M., Sadeghi, A., and Wagner, G.: Improved spectroscopic parameters of methane in the MIR for atmospheric remote sensing, in High Resolution Molecular Spectroscopy 2013 meeting, Budapest, Hungary, 2013.

Duchatelet, P., Demoulin, P., Hase, F., Ruhnke, R., Feng, W., Chipperfield, M. P., Bernath, P. F., Boone, C. D., Walker, K. A., and Mahieu, E.: Hydrogen fluoride total and partial column time series above the Jungfraujoch from long-term FTIR measurements: Impact of the line-shape model, characterization of the error budget and seasonal cycle, and comparison with satellite and model data, J. Geophys. Res., 115, D22306, doi:10.1029/2010JD014677, 2010.

European Commission: Emission Database for Global Atmospheric Research (EDGAR), release version 4.2, Tech. rep., Joint Research Centre (JRC)/Netherlands Environmental Assessment Agency (PBL), available at: http://edgar.jrc.ec.europa.eu (last access: 8 February 2017), 2011.

Fogal, P. F., LeBlanc, L. M., and Drummond, J. R.: The Polar Environment Atmospheric Research Laboratory (PEARL): Sounding the Atmosphere at 80 North, Arctic, 66, 377-386, 2013.

Franco, B., Bader, W., Toon, G. C., Bray, C., Perrin, A., Fischer, E. V., Sudo, K., Boone, C. D., Bovy, B., Lejeune, B., Servais, C., and Mahieu, E.: Retrieval of ethane from ground-based FTIR solar spectra using improved spectroscopy: Recent burden increase above Jungfraujoch, J. Quant. Spectrosc. Ra., 160, 36-49, doi:10.1016/j.jqsrt.2015.03.017, 2015.

Franco, B., Mahieu, E., Emmons, L. K., Tzompa-Sosa, Z. A., Fischer, E. V., Sudo, K., Bovy, B., Conway, S., Griffin, D., Hannigan, J. W., Strong, K., and Walker, K. A.: Evaluating ethane and methane emissions associated with the development of oil and natural gas extraction in North America, Environ. Res. Lett., 11, 44010, doi:10.1088/1748-9326/11/4/044010, 2016.

Frankenberg, C., Aben, I., Bergamaschi, P., Dlugokencky, E. J., van Hees, R., Houweling, S., van der Meer, P., Snel, R., and Tol, P.: Global column-averaged methane mixing ratios from 2003 to 2009 as derived from SCIAMACHY: Trends and variability, J. Geophys. Res., 116, D04302, doi:10.1029/2010JD014849, 2011.

Fraser, A., Miller, C. C., Palmer, P. I., Deutscher, N. M., Jones, N. B., and Griffith, D. W. T.: The Australian methane budget: Interpreting surface and train-borne measurements using a chemistry transport model, J. Geophys. Res., 116, D20306, doi:10.1029/2011JD015964, 2011.

Fung, I., John, J., Lerner, J., Matthews, E., Prather, M., Steele, L. P., and Fraser, P. J.: Three-dimensional model synthesis of the global methane cycle, J. Geophys. Res., 96, 13033, doi:10.1029/91JD01247, 1991.

Gardiner, T., Forbes, A., de Mazière, M., Vigouroux, C., Mahieu, E., Demoulin, P., Velazco, V., Notholt, J., Blumenstock, T., Hase, F., Kramer, I., Sussmann, R., Stremme, W., Mellqvist, J., Strandberg, A., Ellingsen, K., and Gauss, M.: Trend analysis of greenhouse gases over Europe measured by a network of ground-based remote FTIR instruments, Atmos. Chem. Phys., 8, 6719-6727, doi:10.5194/acp-8-6719-2008, 2008.

Gierczak, T., Talukdar, R. K., Herndon, S. C., Vaghjiani, G. L., and Ravishankara, A. R.: Rate Coefficients for the Reactions of Hy- 
droxyl Radicals with Methane and Deuterated Methanes, J. Phys. Chem. A, 101, 3125-3134, doi:10.1021/jp963892r, 1997.

Griffith, D. W. T., Jones, N. B., and Matthews, W. A.: Interhemispheric ratio and annual cycle of carbonyl sulfide (OCS) total column from ground-based solar FTIR spectra, J. Geophys. Res., 103, 8447, doi:10.1029/97JD03462, 1998.

Grooß, J.-U. and Russell III, J. M.: Technical note: A stratospheric climatology for $\mathrm{O}_{3}, \mathrm{H}_{2} \mathrm{O}, \mathrm{CH}_{4}, \mathrm{NO}_{x}, \mathrm{HCl}$ and $\mathrm{HF}$ derived from HALOE measurements, Atmos. Chem. Phys., 5, 2797-2807, doi:10.5194/acp-5-2797-2005, 2005.

Gunson, M. R., Abbas, M. M., Abrams, M. C., Allen, M., Brown, L. R., Brown, T. L., Chang, A. Y., Goldman, A., Irion, F. W., Lowes, L. L., Mahieu, E., Manney, G. L., Michelsen, H. A., Newchurch, M. J., Rinsland, C. P., Salawitch, R. J., Stiller, G. P., Toon, G. C., Yung, Y. L., and Zander, R.: The Atmospheric Trace Molecule Spectroscopy (ATMOS) Experiment: Deployment on the ATLAS space shuttle missions, Geophys. Res. Lett., 23, 2333-2336, doi:10.1029/96GL01569, 1996.

Hase, F.: Inversion von Spurengasprofilen aus hochaufgelösten bodengebundenen FTIR-Messungen in absorption, Karlsruhe, Germany, 2000.

Hase, F., Hannigan, J. W., Coffey, M. T., Goldman, A., Höpfner, M., Jones, N. B., Rinsland, C. P., and Wood, S. W.: Intercomparison of retrieval codes used for the analysis of high-resolution, ground-based FTIR measurements, J. Quant. Spectrosc. Ra., 87, 25-52, doi:10.1016/j.jqsrt.2003.12.008, 2004.

Hausmann, P., Sussmann, R., and Smale, D.: Contribution of oil and natural gas production to renewed increase in atmospheric methane (2007-2014): top-down estimate from ethane and methane column observations, Atmos. Chem. Phys., 16, 3227-3244, doi:10.5194/acp-16-3227-2016, 2016.

Helmig, D., Rossabi, S., Hueber, J., Tans, P., Montzka, S. A., Masarie, K., Thoning, K., Plass-Duelmer, C., Claude, A., Carpenter, L. J., Lewis, A. C., Punjabi, S., Reimann, S., Vollmer, M. K., Steinbrecher, R., Hannigan, J. W., Emmons, L. K., Mahieu, E., Franco, B., Smale, D., and Pozzer, A.: Reversal of global atmospheric ethane and propane trends largely due to US oil and natural gas production, Nat. Geosci., 9, 490-495, doi:10.1038/ngeo2721, 2016.

Henne, S., Furger, M., Nyeki, S., Steinbacher, M., Neininger, B., de Wekker, S. F. J., Dommen, J., Spichtinger, N., Stohl, A., and Prévôt, A. S. H.: Quantification of topographic venting of boundary layer air to the free troposphere, Atmos. Chem. Phys., 4, 497509, doi:10.5194/acp-4-497-2004, 2004.

Henne, S., Furger, M., and Prévôt, A. H.: Climatology of Mountain Venting-Induced Elevated Moisture Layers in the Lee of the Alps, J. Appl. Meteorol., 44, 620-633, doi:10.1175/JAM2217.1, 2005.

Henne, S., Brunner, D., Folini, D., Solberg, S., Klausen, J., and Buchmann, B.: Assessment of parameters describing representativeness of air quality in-situ measurement sites, Atmos. Chem. Phys., 10, 3561-3581, doi:10.5194/acp-10-3561-2010, 2010.

Irion, F. W., Moyer, E. J., Gunson, M. R., Rinsland, C. P., Yung, Y. L., Michelsen, H. A., Salawitch, R. J., Chang, A. Y., Newchurch, M. J., Abbas, M. M., Abrams, M. C., and Zander, R.: Stratospheric observations of CH3D and HDO from ATMOS infrared solar spectra: Enrichments of deuterium in methane and implications for HD, Geophys. Res. Lett., 23, 2381-2384, doi:10.1029/96GL01402, 1996.
Kaplan, J. O.: Wetlands at the Last Glacial Maximum: Distribution and methane emissions, Geophys. Res. Lett., 29, 1079, doi:10.1029/2001GL013366, 2002.

Kirschke, S., Bousquet, P., Ciais, P., Saunois, M., Canadell, J. G., Dlugokencky, E. J., Bergamaschi, P., Bergmann, D., Blake, D. R., Bruhwiler, L., Cameron-Smith, P., Castaldi, S., Chevallier, F., Feng, L., Fraser, A., Heimann, M., Hodson, E. L., Houweling, S., Josse, B., Fraser, P. J., Krummel, P. B., Lamarque, J.F., Langenfelds, R. L., Le Quéré, C., Naik, V., O’Doherty, S., Palmer, P. I., Pison, I., Plummer, D., Poulter, B., Prinn, R. G., Rigby, M., Ringeval, B., Santini, M., Schmidt, M., Shindell, D. T., Simpson, I. J., Spahni, R., Steele, L. P., Strode, S. A., Sudo, K., Szopa, S., van der Werf, G. R., Voulgarakis, A., van Weele, M., Weiss, R. F., Williams, J. E., and Zeng, G.: Three decades of global methane sources and sinks, Nat. Geosci., 6, 813-823, doi:10.1038/ngeo1955, 2013.

Kort, E. A., Smith, M. L., Murray, L. T., Gvakharia, A., Brandt, A. R., Peischl, J., Ryerson, T. B., Sweeney, C., and Travis, K.: Fugitive emissions from the Bakken shale illustrate role of shale production in global ethane shift, Geophys. Res. Lett., 43, 46174623, doi:10.1002/2016GL068703, 2016.

Kreipl, S.: Messung des Aerosoltransports am Alpennordrand mittels Laserradar (Lidar), Friedrich-Alexander-Universität Erlangen-Nürnberg, Erlangen-Nürnberg, Germany, 2006.

Kulawik, S., Wunch, D., O’Dell, C., Frankenberg, C., Reuter, M., Oda, T., Chevallier, F., Sherlock, V., Buchwitz, M., Osterman, G., Miller, C. E., Wennberg, P. O., Griffith, D., Morino, I., Dubey, M. K., Deutscher, N. M., Notholt, J., Hase, F., Warneke, T., Sussmann, R., Robinson, J., Strong, K., Schneider, M., De Mazière, M., Shiomi, K., Feist, D. G., Iraci, L. T., and Wolf, J.: Consistent evaluation of ACOS-GOSAT, BESD-SCIAMACHY, CarbonTracker, and MACC through comparisons to TCCON, Atmos. Meas. Tech., 9, 683-709, doi:10.5194/amt-9-683-2016, 2016.

Langerock, B., De Mazière, M., Hendrick, F., Vigouroux, C., Desmet, F., Dils, B., and Niemeijer, S.: Description of algorithms for co-locating and comparing gridded model data with remote-sensing observations, Geosci. Model Dev., 8, 911-921, doi:10.5194/gmd-8-911-2015, 2015.

Lelieveld, J.: Stability of tropospheric hydroxyl chemistry, J. Geophys. Res., 107, 4715, doi:10.1029/2002JD002272, 2002.

Logan, J. A., Prather, M. J., Wofsy, S. C., and McElroy, M. B.: Tropospheric chemistry: A global perspective, J. Geophys. Res., 86, 7210, doi:10.1029/JC086iC08p07210, 1981.

Lyon, D. R., Alvarez, R. A., Zavala-Araiza, D., Brandt, A. R., Jackson, R. B., and Hamburg, S. P.: Aerial Surveys of Elevated Hydrocarbon Emissions from Oil and Gas Production Sites, Environ. Sci. Technol., 50, 4877-4886, doi:10.1021/acs.est.6b00705, 2016.

Mahieu, E., Chipperfield, M. P., Notholt, J., Reddmann, T., Anderson, J., Bernath, P. F., Blumenstock, T., Coffey, M. T., Dhomse, S. S., Feng, W., Franco, B., Froidevaux, L., Griffith, D. W. T., Hannigan, J. W., Hase, F., Hossaini, R., Jones, N. B., Morino, I., Murata, I., Nakajima, H., Palm, M., Paton-Walsh, C., Russel III, J. M., Schneider, M., Servais, C., Smale, D., and Walker, K. A.: Recent Northern Hemisphere stratospheric $\mathrm{HCl}$ increase due to atmospheric circulation changes, Nature, 515, 104-107, doi:10.1038/nature13857, 2014. 
Montzka, S. A., Krol, M., Dlugokencky, E., Hall, B., Jockel, P., and Lelieveld, J.: Small Interannual Variability of Global Atmospheric Hydroxyl, Science, 331, 67-69, doi:10.1126/science.1197640, 2011.

Nisbet, E. G., Dlugokencky, E. J., and Bousquet, P.: Methane on the rise-again, Science, 343, 493-495, doi:10.1126/science.1247828, 2014.

Nyeki, S., Kalberer, M., Colbeck, I., de Wekker, S. F. J., Furger, M., Gäggeler, H. W., Kossmann, M., Lugauer, M., Steyn, D., Weingartner, E., Wirth, M., and Baltensperger, U.: Convective boundary layer evolution to $4 \mathrm{~km}$ asl over High-Alpine terrain: airborne Lidar observations in the Alps, Geophys. Res. Lett., 27, 689-692, 2000.

Okamoto, S. and Tanimoto, H.: A review of atmospheric chemistry observations at mountain sites, Prog. Earth Planet. Sci., 3, 34, doi:10.1186/s40645-016-0109-2, 2016.

Park, R., Jacob, D. J., Field, B. D., Yantosca, R. M., and Chin, M.: Natural and transboundary pollution influences on sulfate-nitrate-ammonium aerosols in the United States: Implications for policy, J. Geophys. Res., 109, D15204, doi:10.1029/2003JD004473, 2004.

Park, R., Jacob, D., Kumar, N., and Yantosca, R.: Regional visibility statistics in the United States: Natural and transboundary pollution influences, and implications for the Regional Haze Rule, Atmos. Environ., 40, 5405-5423, doi:10.1016/j.atmosenv.2006.04.059, 2006.

Peischl, J., Karion, A., Sweeney, C., Kort, E. A., Smith, M. L., Brandt, A. R., Yeskoo, T., Aikin, K. C., Conley, S. A., Gvakharia, A., Trainer, M., Wolter, S., and Ryerson, T. B.: Quantifying atmospheric methane emissions from oil and natural gas production in the Bakken shale region of North Dakota, J. Geophys. Res.-Atmos., 121, 6101-6111, doi:10.1002/2015JD024631, 2016.

Pickett-Heaps, C. A., Jacob, D. J., Wecht, K. J., Kort, E. A., Wofsy, S. C., Diskin, G. S., Worthy, D. E. J., Kaplan, J. O., Bey, I., and Drevet, J.: Magnitude and seasonality of wetland methane emissions from the Hudson Bay Lowlands (Canada), Atmos. Chem. Phys., 11, 3773-3779, doi:10.5194/acp-11-3773-2011, 2011.

Pison, I., Ringeval, B., Bousquet, P., Prigent, C., and Papa, F.: Stable atmospheric methane in the 2000s: key-role of emissions from natural wetlands, Atmos. Chem. Phys., 13, 11609-11623, doi:10.5194/acp-13-11609-2013, 2013.

Prather, M. J., Holmes, C. D., and Hsu, J.: Reactive greenhouse gas scenarios: Systematic exploration of uncertainties and the role of atmospheric chemistry, Geophys. Res. Lett., 39, L09803, doi:10.1029/2012GL051440, 2012.

Prinn, R. G., Weiss, R. F., Fraser, P. J., Simmonds, P. G., Cunnold, D. M., Alyea, F. N., O'Doherty, S., Salameh, P., Miller, B. R., Huang, J., Wang, R. H. J., Hartley, D. E., Harth, C., Steele, L. P., Sturrock, G., Midgley, P. M., and McCulloch, A.: A history of chemically and radiatively important gases in air deduced from ALE/GAGE/AGAGE, J. Geophys. Res.-Atmos., 105, 17751-17792, doi:10.1029/2000JD900141, 2000.

Quay, P., Stutsman, J., Wilbur, D., Snover, A., Dlugokencky, E., and Brown, T.: The isotopic composition of atmospheric methane, Glob. Biogeochem. Cy., 13, 445-461, doi:10.1029/1998GB900006, 1999.

Reimann, S.: Halogenated greenhouse gases at the Swiss High Alpine Site of Jungfraujoch (3580 m a.s.1.): Continuous measure- ments and their use for regional European source allocation, J. Geophys. Res., 109, D05307, doi:10.1029/2003JD003923, 2004.

Rigby, M., Prinn, R. G., Fraser, P. J., Simmonds, P. G., Langenfelds, R. L., Huang, J., Cunnold, D. M., Steele, L. P., Krummel, P. B., Weiss, R. F., O’Doherty, S., Salameh, P. K., Wang, H. J., Harth, C. M., Mühle, J., and Porter, L. W.: Renewed growth of atmospheric methane, Geophys. Res. Lett., 35, L22805, doi:10.1029/2008GL036037, 2008.

Ringeval, B., de Noblet-Ducoudré, N., Ciais, P., Bousquet, P., Prigent, C., Papa, F., and Rossow, W. B.: An attempt to quantify the impact of changes in wetland extent on methane emissions on the seasonal and interannual time scales, Glob. Biogeochem. Cy., 24, GB2003, doi:10.1029/2008GB003354, 2010.

Rinsland, C. P., Jones, N. B., Connor, B. J., Logan, J. A., Pougatchev, N. S., Goldman, A., Murcray, F. J., Stephen, T. M., Pine, A. S., Zander, R., Mahieu, E., Demoulin, P., Rinsland, C. P., Jones, N. B., Connor, B. J., Logan, J. A., Pougatchev, N. S., Goldman, A., Murcray, F. J., Stephen, T. M., Pine, A. S., Zander, R., Mahieu, E., Demoulin, P., Rinsland, C. P., Jones, N. B., Connor, B. J., Logan, J. A., Pougatchev, N. S., Goldman, A., Murcray, F. J., Stephen, T. M., Pine, A. S., Zander, R., Mahieu, E., and Demoulin, P.: Northern and southern hemisphere groundbased infrared spectroscopic measurements of tropospheric carbon monoxide and ethane, J. Geophys. Res., 103, 28197-28217, doi:10.1029/98JD02515, 1998.

Rinsland, C. P., Goldman, A., Elkins, J. W., Chiou, L. S., Hannigan, J. W., Wood, S. W., Mahieu, E., and Zander, R.: Long-term trend of $\mathrm{CH}_{4}$ at northern mid-latitudes: Comparison between ground-based infrared solar and surface sampling measurements, J. Quant. Spectrosc. Ra., 97, 457-466, doi:10.1016/j.jqsrt.2005.07.002, 2006.

Rodgers, C. D.: Characterization and error analysis of profiles retrieved from remote sounding measurements, J. Geophys. Res., 95, 5587-5595, 1990.

Rothman, L. S., Barbe, A., Chris Benner, D., Brown, L. R., CamyPeyret, C., Carleer, M. R., Chance, K., Clerbaux, C., Dana, V., Devi, V. M., Fayt, A., Flaud, J.-M., Gamache, R. R., Goldman, A., Jacquemart, D., Jucks, K. W., Lafferty, W. J., Mandin, J.-Y., Massie, S. T., Nemtchinov, V., Newnham, D. A., Perrin, A., Rinsland, C. P., Schroeder, J., Smith, K. M., Smith, M. A. H., Tang, K., Toth, R. A., Vander Auwera, J., Varanasi, P., and Yoshino, K.: The HITRAN molecular spectroscopic database: edition of 2000 including updates through 2001, J. Quant. Spectrosc. Ra., 82, 5-44, doi:10.1016/S0022-4073(03)00146-8, 2003.

Rothman, L. S., Gordon, I. E., Barbe, A., Benner, D. C., Bernath, P. F., Birk, M., Boudon, V., Brown, L. R., Campargue, A., Champion, J.-P., Chance, K., Coudert, L. H., Dana, V., Devi, V. M., Fally, S., Flaud, J.-M., Gamache, R. R., Goldman, A., Jacquemart, D., Kleiner, I., Lacome, N., Lafferty, W. J., Mandin, J.-Y., Massie, S. T., Mikhailenko, S. N., Miller, C. E., Moazzen-Ahmadi, N., Naumenko, O. V., Nikitin, A. V., Orphal, J., Perevalov, V. I., Perrin, A., Predoi-Cross, A., Rinsland, C. P., Rotger, M., Šimečková, M., Smith, M. A. H., Sung, K., Tashkun, S. A., Tennyson, J., Toth, R. A., Vandaele, A. C., and Vander Auwera, J.: The HITRAN 2008 molecular spectroscopic database, J. Quant. Spectrosc. Ra., 110, 533-572, doi:10.1016/j.jqsrt.2009.02.013, 2009.

Rothman, L. S., Gordon, I. E., Babikov, Y., Barbe, A., Chris Benner, D., Bernath, P. F., Birk, M., Bizzocchi, L., Boudon, 
V., Brown, L. R., Campargue, A., Chance, K., Cohen, E. A., Coudert, L. H., Devi, V. M., Drouin, B. J., Fayt, A., Flaud, J.-M., Gamache, R. R., Harrison, J. J., Hartmann, J.-M., Hill, C., Hodges, J. T., Jacquemart, D., Jolly, A., Lamouroux, J., Le Roy, R. J., Li, G., Long, D. A., Lyulin, O. M., Mackie, C. J., Massie, S. T., Mikhailenko, S., Müller, H. S. P., Naumenko, O. V., Nikitin, A. V., Orphal, J., Perevalov, V., Perrin, A., Polovtseva, E. R., Richard, C., Smith, M. A. H., Starikova, E., Sung, K., Tashkun, S., Tennyson, J., Toon, G. C., Tyuterev, V. G., and Wagner, G.: The HITRAN2012 molecular spectroscopic database, J. Quant. Spectrosc. Ra., 130, 4-50, doi:10.1016/j.jqsrt.2013.07.002, 2013.

Rudolph, J.: The tropospheric distribution and budget of ethane, J. Geophys. Res., 100, 11369, doi:10.1029/95JD00693, 1995.

Saueressig, G., Crowley, J. N., Bergamaschi, P., Brühl, C., Brenninkmeijer, C. A. M., and Fischer, H.: Carbon 13 and D kinetic isotope effects in the reactions of $\mathrm{CH}_{4}$ with $\mathrm{O}\left({ }^{1} \mathrm{D}\right)$ and $\mathrm{OH}$ : New laboratory measurements and their implications for the isotopic composition of stratospheric methane, J. Geophys. Res., 106, 23127, doi:10.1029/2000JD000120, 2001.

Schaefer, H., Fletcher, S. E. M., Veidt, C., Lassey, K. R., Brailsford, G. W., Bromley, T. M., Dlugokencky, E. J., Michel, S. E., Miller, J. B., Levin, I., Lowe, D. C., Martin, R. J., Vaughn, B. H., and White, J. W. C.: A 21st-century shift from fossil-fuel to biogenic methane emissions indicated by ${ }^{13} \mathrm{CH}_{4}$, Science, 352 , 80-84, doi:10.1126/science.aad2705, 2016.

Schwietzke, S., Griffin, W. M., Matthews, H. S., and Bruhwiler, L. M. P.: Global Bottom-Up Fossil Fuel Fugitive Methane and Ethane Emissions Inventory for Atmospheric Modeling, ACS Sustain. Chem. Eng., 2, 1992-2001, doi:10.1021/sc500163h, 2014.

Sepúlveda, E., Schneider, M., Hase, F., García, O. E., GomezPelaez, A., Dohe, S., Blumenstock, T., and Guerra, J. C.: Longterm validation of tropospheric column-averaged $\mathrm{CH}_{4}$ mole fractions obtained by mid-infrared ground-based FTIR spectrometry, Atmos. Meas. Tech., 5, 1425-1441, doi:10.5194/amt-5-14252012, 2012.

Sepúlveda, E., Schneider, M., Hase, F., Barthlott, S., Dubravica, D., García, O. E., Gomez-Pelaez, A., González, Y., Guerra, J. C., Gisi, M., Kohlhepp, R., Dohe, S., Blumenstock, T., Strong, K., Weaver, D., Palm, M., Sadeghi, A., Deutscher, N. M., Warneke, T., Notholt, J., Jones, N., Griffith, D. W. T., Smale, D., Brailsford, G. W., Robinson, J., Meinhardt, F., Steinbacher, M., Aalto, T., and Worthy, D.: Tropospheric $\mathrm{CH}_{4}$ signals as observed by NDACC FTIR at globally distributed sites and comparison to GAW surface in situ measurements, Atmos. Meas. Tech., 7, 2337-2360, doi:10.5194/amt-7-2337-2014, 2014

Simpson, I. J., Sulbaek Andersen, M. P., Meinardi, S., Bruhwiler, L., Blake, N. J., Helmig, D., Rowland, F. S., and Blake, D. R.: Long-term decline of global atmospheric ethane concentrations and implications for methane, Nature, 488, 490-494, doi:10.1038/nature11342, 2012.

Snover, A. K. and Quay, P. D.: Hydrogen and carbon kinetic isotope effects during soil uptake of atmospheric methane, Glob. Biogeochem. Cy., 14, 25-39, doi:10.1029/1999GB900089, 2000.

Snover, A. K., Quay, P. D., and Hao, W. M.: The D/H content of methane emitted from biomass burning, Glob. Biogeochem. Cy., 14, 11-24, doi:10.1029/1999GB900075, 2000.
Solomon, S., Rosenlof, K. H., Portmann, R. W., Daniel, J. S., Davis, S. M., Sanford, T. J., and Plattner, G.-K.: Contributions of Stratospheric Water Vapor to Decadal Changes in the Rate of Global Warming, Science, 327, 1219-1223, doi:10.1126/science.1182488, 2010.

Spahni, R., Wania, R., Neef, L., van Weele, M., Pison, I., Bousquet, P., Frankenberg, C., Foster, P. N., Joos, F., Prentice, I. C., and van Velthoven, P.: Constraining global methane emissions and uptake by ecosystems, Biogeosciences, 8, 1643-1665, doi:10.5194/bg8-1643-2011, 2011.

Stocker, T. F., Qin, D., Plattner, G.-K., Tignor, M., Allen, S. K., Boschung, J., Nauels, A., Xia, Y., Bex, V., and Midgley, P. M.: The Physical Science Basis, Contribution of Working Group I to the Fifth Assessment Report of the Intergovernmental Panel on Climate Change, Cambridge, Cambridge, UK, New York, NY, USA, 2013.

Strahan, S. E., Oman, L. D., Douglass, A. R., and Coy, L.: Modulation of Antarctic vortex composition by the quasibiennial oscillation, Geophys. Res. Lett., 42, 4216-4223, doi:10.1002/2015GL063759, 2015.

Strong, K., Wolff, M. A., Kerzenmacher, T. E., Walker, K. A., Bernath, P. F., Blumenstock, T., Boone, C., Catoire, V., Coffey, M., De Mazière, M., Demoulin, P., Duchatelet, P., Dupuy, E., Hannigan, J., Höpfner, M., Glatthor, N., Griffith, D. W. T., Jin, J. J., Jones, N., Jucks, K., Kuellmann, H., Kuttippurath, J., Lambert, A., Mahieu, E., McConnell, J. C., Mellqvist, J., Mikuteit, S., Murtagh, D. P., Notholt, J., Piccolo, C., Raspollini, P., Ridolfi, M., Robert, C., Schneider, M., Schrems, O., Semeniuk, K., Senten, C., Stiller, G. P., Strandberg, A., Taylor, J., Tétard, C., Toohey, M., Urban, J., Warneke, T., and Wood, S.: Validation of ACE-FTS $\mathrm{N}_{2} \mathrm{O}$ measurements, Atmos. Chem. Phys., 8, 47594786, doi:10.5194/acp-8-4759-2008, 2008.

Sussmann, R. and Schäfer, K.: Infrared spectroscopy of tropospheric trace gases: combined analysis of horizontal and vertical column abundances, Appl. Opt., 36, 735-741, doi:10.1364/AO.36.000735, 1997.

Sussmann, R., Forster, F., Rettinger, M., and Jones, N.: Strategy for high-accuracy-and-precision retrieval of atmospheric methane from the mid-infrared FTIR network, Atmos. Meas. Tech., 4, 1943-1964, doi:10.5194/amt-4-1943-2011, 2011.

Sussmann, R., Forster, F., Rettinger, M., and Bousquet, P.: Renewed methane increase for five years (2007-2011) observed by solar FTIR spectrometry, Atmos. Chem. Phys., 12, 4885-4891, doi:10.5194/acp-12-4885-2012, 2012.

Tikhonov, A.: On the solution of incorrectly stated problems and a method of regularization, Dokl. Acad. Nauk SSSR, 151, 501504, 1963.

Turner, A. J., Jacob, D. J., Wecht, K. J., Maasakkers, J. D., Lundgren, E., Andrews, A. E., Biraud, S. C., Boesch, H., Bowman, K. W., Deutscher, N. M., Dubey, M. K., Griffith, D. W. T., Hase, F., Kuze, A., Notholt, J., Ohyama, H., Parker, R., Payne, V. H., Sussmann, R., Sweeney, C., Velazco, V. A., Warneke, T., Wennberg, P. O., and Wunch, D.: Estimating global and North American methane emissions with high spatial resolution using GOSAT satellite data, Atmos. Chem. Phys., 15, 7049-7069, doi:10.5194/acp-15-7049-2015, 2015.

Turner, A. J., Jacob, D. J., Benmergui, J., Wofsy, S. C., Maasakkers, J. D., Butz, A., Hasekamp, O., Biraud, S. C., and Dlugokencky, E.: A large increase in US methane emis- 
sions over the past decade inferred from satellite data and surface observations, Geophys. Res. Lett., 43, 2218-2224, doi:10.1002/2016GL067987, 2016.

Turner, J., Colwell, S. R., Marshall, G. J., Lachlan-Cope, T. A., Carleton, A. M., Jones, P. D., Lagun, V., Reid, P. A., and Iagovkina, S.: The SCAR READER Project: Toward a High-Quality Database of Mean Antarctic Meteorological Observations, J. Climate, 17, 2890-2898, doi:10.1175/15200442(2004)017<2890:TSRPTA>2.0.CO;2, 2004.

Tyler, S. C., Ajie, H. O., Rice, A. L., Cicerone, R. J., and Tuazon, E. C.: Experimentally determined kinetic isotope effects in the reaction of $\mathrm{CH}_{4}$ with $\mathrm{Cl}$ : Implications for atmospheric $\mathrm{CH}_{4}$, Geophys. Res. Lett., 27, 1715-1718, doi:10.1029/1999GL011168, 2000.

Wang, J. S., Logan, J. A., McElroy, M. B., Duncan, B. N., Megretskaia, I. A., and Yantosca, R. M.: A 3-D model analysis of the slowdown and interannual variability in the methane growth rate from 1988 to 1997, Glob. Biogeochem. Cy., 18, GB3011, doi:10.1029/2003GB002180, 2004.

van der Werf, G. R., Randerson, J. T., Giglio, L., Collatz, G. J., Mu, M., Kasibhatla, P. S., Morton, D. C., DeFries, R. S., Jin, Y., and van Leeuwen, T. T.: Global fire emissions and the contribution of deforestation, savanna, forest, agricultural, and peat fires (19972009), Atmos. Chem. Phys., 10, 11707-11735, doi:10.5194/acp10-11707-2010, 2010.

Whaley, C. H., Strong, K., Jones, D. B. A., Walker, T. W., Jiang, Z., Henze, D. K., Cooke, M. A., McLinden, C. A., Mittermeier, R. L., Pommier, M., and Fogal, P. F.: Toronto area ozone: Long-term measurements and modeled sources of poor air quality events, J. Geophys. Res.-Atmos., 120, 11368-11390, doi:10.1002/2014JD022984, 2015.

Whiticar, M. and Schaefer, H.: Constraining past global tropospheric methane budgets with carbon and hydrogen isotope ratios in ice, Philos. T. R. Soc. A, 365, 1793-1828, doi:10.1098/rsta.2007.2048, 2007.

Wiacek, A., Taylor, J. R., Strong, K., Saari, R., Kerzenmacher, T. E., Jones, N. B., and Griffith, D. W. T.: Ground-based solar absorption FTIR spectroscopy: Characterization of retrievals and first results from a novel optical design instrument at a new NDACC complementary station, J. Atmos. Ocean. Tech., 24, 432-448, doi:10.1175/JTECH1962.1, 2007.
World Meteorological Organization (WMO): Greenhouse Gas Bulletin No. 10, Geneva, Switzerland, 2014.

Yevich, R. and Logan, J. A.: An assessment of biofuel use and burning of agricultural waste in the developing world, Glob. Biogeochem. Cy., 17, 1095, doi:10.1029/2002GB001952, 2003.

Zander, R., Mahieu, E., Demoulin, P., Duchatelet, P., Roland, G., Servais, C., De Mazière, M., Reimann, S., and Rinsland, C. P.: Our changing atmosphere: Evidence based on long-term infrared solar observations at the Jungfraujoch since 1950, Sci. Total Environ., 391, 184-195, doi:10.1016/j.scitotenv.2007.10.018, 2008.

Zellweger, C., Ammann, M., Buchmann, B., Hofer, P., Lugauer, M., Rüttimann, R., Streit, N., Weingartner, E., and Baltensperger, U.: Summertime $\mathrm{NO}_{y}$ speciation at the Jungfraujoch, $3580 \mathrm{~m}$ above sea level, Switzerland, J. Geophys. Res.-Atmos., 105, 66556667, doi:10.1029/1999JD901126, 2000.

Zellweger, C., Forrer, J., Hofer, P., Nyeki, S., Schwarzenbach, B., Weingartner, E., Ammann, M., and Baltensperger, U.: Partitioning of reactive nitrogen $\left(\mathrm{NO}_{y}\right)$ and dependence on meteorological conditions in the lower free troposphere, Atmos. Chem. Phys., 3, 779-796, doi:10.5194/acp-3-779-2003, 2003.

Zhang, L., Jacob, D. J., Downey, N. V., Wood, D. A., Blewitt, D., Carouge, C. C., van Donkelaar, A., Jones, D. B. A., Murray, L. T., and Wang, Y.: Improved estimate of the policy-relevant background ozone in the United States using the GEOS-Chem global model with $1 / 2^{\circ} \times 2 / 3^{\circ}$ horizontal resolution over North America, Atmos. Environ., 45,, 6769-6776, doi:10.1016/j.atmosenv.2011.07.054, 2011.

Zhang, L., Jacob, D. J., Knipping, E. M., Kumar, N., Munger, J. W., Carouge, C. C., van Donkelaar, A., Wang, Y. X., and Chen, D.: Nitrogen deposition to the United States: distribution, sources, and processes, Atmos. Chem. Phys., 12, 4539-4554, doi:10.5194/acp-12-4539-2012, 2012. 